\title{
A GDP és GNI közötti eltérés hazai és régiós alakulása*
}

\author{
Balogh Eszter - Boldizsár Anna-Gerlaki Bence - Kóczián Balázs
}

A globalizáció elöretörésével a termelési tényezők határon átnyúló mozgása miatt a hazai gazdaság termelése és a termelés által generált rezidenseknek jutó elsődleges jövedelem elnyilik egymástól. A GDP-GNI közötti eltérés megmutatja a hazai gazdaság teljesítménye és a gazdaság egyes szektorainak jutó elsődleges jövedelem közötti különbséget, illetve hasznos információt ad az ország felhalmozott nettó külföldi kötelezettség-állományának folyó terheiröl. Tanulmányunkban bemutatjuk a GDP-GNI rés alakulását befolyásoló tényezőket az elmúlt években, majd a rendelkezésre álló adatokat ágazati és országbontásban vizsgálva nézzük meg, hogyan változott a gazdaság egyes szektorainak jövedelme. A nemzetközi folyamatok és régiós tendenciák elemzésével vizsgáljuk a GDP és GNI közötti eltérés és a gazdaságok fejlettsége közötti összefüggést, majd igyekszünk feltérképezni azokat az irányvonalakat, amelyek a hazai GDP és GNI közötti eltérést rövid, illetve hosszú távon meghatározzák. Megállapitjuk, hogy a GDP-GNI rés a külföldi tulajdonú vállalatok jövedelmének várható emelkedése miatt rövid távon növekedhet, hosszú távú alakulása pedig jelentősen függ attól, hogy a magyar gazdaság nyugati országokhoz történő felzárkózása külföldi vagy belföldi forrásokból valósul meg.

Journal of Economic Literature (JEL) kódok: E01, F41, F43

Kulcsszavak: bruttó nemzeti jövedelem, GDP-GNI rés, elsődleges jövedelemegyenleg

\section{Bevezetés}

Az elmúlt évtizedekben a közgazdaságtanban egyre nagyobb igény jelentkezett olyan makrogazdasági indikátorok iránt, amelyek pontosabb képet adhatnak a nemzetek rendelkezésre álló jövedelméröl, mint a bruttó hazai termék (Gross Domestic Product, GDP), mivel ez utóbbi mutató a lakosság jövedelmi helyzetéről, szociális és gazdasági jólétéről nem nyújt teljes képet (BEA 2015). Számos tanulmány rávilágított, hogy a döntéshozatal során nem elegendő a kibocsátás szintjének vizsgálata, a gazdaságpolitikai-társadalmi céltól függően különböző alternatívák

\footnotetext{
* A jelen kiadványban megjelenő írások a szerzők nézeteit tartalmazzák, ami nem feltétlenül egyezik a Magyar Nemzeti Bank hivatalos álláspontjával.
}

Balogh Eszter a Magyar Nemzeti Bank junior elemzője.E-mail: baloghes@mnb.hu Boldizsár Anna a Magyar Nemzeti Bank elemzője. E-mail: boldizsara@mnb.hu Gerlaki Bence a Magyar Nemzeti Bank junior elemzője. E-mail: gerlakib@mnb.hu Kóczián Balázs a Magyar Nemzeti Bank közgazdasági elemzője. E-mail: koczianb@mnb.hu

A magyar nyelvű kézirat első változata 2018. március 12-én érkezett szerkesztőségünkbe. 
és kiegészítések lehetnek szükségesek (Costanza et al 2009; Stiglitz et al 2008). A tőke és a munkaerő mobilitásának emelkedése ráerősített az új gazdasági mutatók használatának szükségességére (Capelli - Vaggi 2013), aminek hátterében elsősorban az állt, hogy az intenzív tőkemozgások miatt az adott ország területén végzett termelés és a gazdasági szereplők jövedelmei közötti különbség a fejlett és a fejlődő országokban egyaránt nőtt. Ennek következtében a csak GDP-központú elemzések hiányos képet mutathatnak, hiszen nem reprezentálják kellőképpen azt, milyen mértékben részesülnek a rezidens gazdasági szereplők az ország területén megtermelt jövedelemből.

Magyarországon is régóta foglalkoztatja a gazdasági döntéshozókat, hogy valójában mennyi jövedelem kerül a belföldi szektorokhoz az itthon előállított össztermékból, és mennyi jövedelem hagyja el az országot. Ennek eredményeképpen fontos tisztában lenni a GDP-t kiegészítő, Magyarország jövedelmi helyzetét jobban megragadó alternatív mutatókkal is. Ilyen mutató többek között a bruttó nemzeti jövedelem (Gross National Income, GNI), amely a GDP-t (ami az ország területén adott időszakban megtermelt jövedelem nagysága) korrigálja a rezidens és nem rezidens szektorok közötti tulajdonosi jövedelem átutalásaival és a szintén az elsődleges jövedelmek között elszámolt folyó transzferekkel. A GNI ebből a szempontból hasznos és könnyen hozzáférhető mutató, ami szorosan összefügg az életminőség más, nem makrogazdasági jellegú indikátoraival (pl. születéskor várható élettartam, gyermekek beiskolázási aránya) (World Bank 2017). Emellett a szakirodalomban ritkábban használt, ugyanakkor hasznos mutató a rendelkezésre álló bruttó nemzeti jövedelem (Gross National Disposable Income, GNDI), ami a GNI-on túl számba veszi a másodlagos jövedelmeknél elszámolt, külföldről származó egyoldalú folyó transzfereket is. A másodlagos jövedelmeken belül azonban van olyan tétel is (pl. a magyar állam uniós befizetései), amely csak az általunk vizsgálandó jövedelmi kategórián kívül eső tőketranszferekkel együtt értelmezhető, így cikkünkben elsősorban a GNI alakulására fókuszálunk. Érdemes ugyanakkor megjegyezni, hogy éppen emiatt további érdekes kutatási irányt jelenthet a közgazdasági irodalomban eddig kevésbé elterjedt, de egy gazdaság végső fogyasztása-beruházása-megtakarítása szempontjából kiemelt jelentőségű, a tőketranszfereket is figyelembe vevő GNDI mutató vizsgálata.

Az elemzésünk középpontjában a GNI, illetve a GNI és GDP közötti rés áll, mivel ebben a mutatóban tükröződik egy nemzetgazdaság termelés által generált jövedelmeinek rezidensek és nem rezidensek közötti (elsődleges) elosztása. Míg a GNDI és a korrigált GNDI számol az egyoldalú jövedelemátutalásokkal, addig a GNI (a bérjövedelmeken és a folyó transzfereken kívül) csak a nettó külföldi kötelezettségvagy követelés-állományon realizált kamat- és FDI-jövedelmet veszi figyelembe. Ebből fakadóan a gazdasági szereplők aktivitásából származó jövedelmeket jobban mutathatja a GNI, hiszen nem tartalmazza a sokszor egyedi tételeknek számító egyoldalú átutalásokat, amelyek hatással lehetnek az ország külfölddel szembeni pozíciójára. A GNI - amellett, hogy számszerűsíti egy gazdaság nettó külföldi kötelezettség állományának folyó terheit - információt ad az adósságnövekedés fenn- 
tarthatóságáról és a külső adósság dinamikájára ható tényezőkről (Oblath 2011). Ebből a szempontból különösen fontos vizsgálni a Magyarországhoz hasonló kis és nyitott országokban a GNI és a GDP-GNI közötti rés alakulását.

A jelentős közvetlentőke-állománnyal rendelkező, feltörekvő országoknál jellemző, hogy a GNI szintje elmarad a GDP nagyságától. Ez legtöbb esetben a külföldi vállalatok profitjához köthető, ami természetesen nem képezi a belföldi szektorok jövedelmét. Érdemes azonban felhívni arra a figyelmet, hogy a GDP GNI-nál nagyobb mértékben való bővülése (és ezáltal a GDP-GNI rés emelkedése) sem feltétlen jelent kedvezőtlen folyamatot egy gazdaság számára - hiszen elképzelhető, hogy a profitkiáramlással járó külföldi befektetések nélkül a GNI szintje még ennél is kisebb szintet ért volna el. Fontos szem előtt tartani, hogy ez nagymértékben függ a külföldi források típusától és a fogadó ország abszorpciós képességétől is (Balatoni - Pitz 2012). Míg a közvetlentőke-befektetésekből megvalósuló beruházásoknál a fogadó ország termelékenysége javulhat, addig a külföldi hitelnél vagy portfólióbefektetéseknél nem számolhatunk ilyen pozitív externáliával. Ebből fakadóan például Magyarországon a FDI-típusú források bizonyultak a legkedvezőbb finanszírozási formának az elmúlt évtizedekben, annak ellenére, hogy az implicit hozamok alapján költségesebb forrásnak tekinthetjük a külföldi hiteleknél vagy a portfólióbefektetéseknél. Az FDI-források közvetett, egyértelmű hatásai (beruházások bővülése, adóbevételek emelkedése, munkahelyteremtés) mellett a közvetlen hatások (technológiai spillover, beszállítók térnyerése nemzetközi piacokon) is kulcsszerepet játszanak a fogadó ország bruttó nemzeti jövedelmének alakulásában.

Írország esete is jó példa arra, hogy a globalizáció mekkora hatást tud gyakorolni egy ország gazdasági mutatóira. Írországban az elmúlt években tapasztalt GDP-növekedés (például 2015-ben 25 százalék) leginkább az ország kedvező adózási feltételeihez kötődő szabad tőkeáramláshoz kapcsolódott, így nem véletlen, hogy az ír statisztikai hivatal munkatársai a GDP helyett más, alternatív mutató(k) használatát támogatják a gazdaság teljesítményének mérésére ${ }^{1}$ (Stapel-Weber - Verrinder 2016). Írország példája rámutat, hogy érdemes pontosabban ismerni a gazdaságban keletkezett jövedelem és a rezidens gazdasági szereplőknek jutó elsődleges jövedelem közötti különbséget megragadó GDP-GNI eltérést - amelynek értéke ebben az országban az egyik legmagasabb nemzetközi összevetésben - és az e mögött meghúzódó tényezőket. Emellett a GDP-GNI-eltérés vizsgálata egy ország külső sérülékenységének szempontjából is fontos, hiszen számszerüsíti azokat a költségeket, amelyeket a külföldi forrásokra fizetett jövedelmek jelentenek egy gazdaság számára.

Jelen tanulmányunkban döntően a magyar GDP-GNI rés elmúlt évekbeli alakulásával, valamint az azt befolyásoló tényezőkkel foglalkozunk. Az első részben röviden

\footnotetext{
${ }^{1}$ A javasolt mutató a GNI-ból indul ki, amelyből kiszűrik a „globalizáció hatásait” is (a hivatalos és a módosított GNI-mutató között kismértékű az eltérés). Az új mutatótól azt várják, hogy stabilabb lesz, és kevésbé érzékenyen reagál egyes sokkokra vagy egyedi hatásokra. A módosított GNI elnyílik ugyan a GDP-től, azonban ez nem jelenti azt, hogy rosszabbak lennének az ír gazdasági szereplők életkörülményei - ugyanakkor az ennek arányában számított adósságmutató magasabb, mint a GDP-arányos, amelynek hatása lehet a gazdaság befektetői megítélésére vagy EU felé történő be-, illetve kifizetéseire.
} 
áttekintjük a GNI pontos definícióját, majd a GDP-GNI rés magyarországi alakulását vizsgáljuk meg. Ezt követően a Magyarország szempontjából különösen fontos közvetlentőke-befektetésekhez kapcsolódó jövedelmek ágazati- és országbontására koncentrálunk. Ezután bemutatjuk, hogy milyen arányban részesül a háztartási, vállalati és állami szektor a bruttó nemzeti jövedelemből, majd áttekintjük a GDPGNI rés alakulását a környező országokban. Rávilágítunk a mutató és a gazdasági fejlettség között fennálló kapcsolatra, s a tanulmány végén kísérletet teszünk az eltérés következő években várható alakulásának meghatározására.

\section{A bruttó nemzeti jövedelem definíciója}

A bruttó nemzeti jövedelem a GDP-ből számolt indikátor, ugyanakkor, míg a GDP a statisztikai értelemben vett területi státusz, addig a GNI a statisztikai értelemben vett rezidensi státusz alapján határozódik meg. Képlettel kifejezve a két mutató közti kapcsolat:

Bruttó nemzeti jövedelem $(G N I)$ = Bruttó hazai termék $(G D P)$

+ Belföldi rezidensek külföldröl kapott elsődleges jövedelmei

- Külföldi rezidenseknek belföldröl fizetett elsődleges jövedelmei

Az elsődleges jövedelmek a munkajövedelmet, a tulajdonosi jövedelmet - ezen belül az FDI-jövedelmet (profitot) és a hitelből származó jövedelmet (kamatot) - illetve bizonyos folyó viszonzatlan átutalásokat ${ }^{2}$ foglalják magukba (KSH 2009):

- munkajövedelem: az átmenetileg (egy évnél rövidebb ideig) külföldön dolgozó magyarok és az átmenetileg Magyarországon dolgozó külföldiek bérjövedelmének egyenlege;

- FDI-jövedelem: a külföldi szereplők Magyarországról származó és a magyarországi szereplők külföldről származó részesedésekhez kapcsolódó jövedelmének különbsége, ami megmutatja, hogy nettó értelemben mekkora az a jövedelem, amely a külföldi jövedelemtulajdonosokat illeti a közvetlentőke-befektetéseik után;

- kamatjövedelem: a belföldiek külföldiekkel szemben fennálló hitelei és hitelviszonyt megtestesítő értékpapír-befektetései (kötvény, kincstárjegy stb.) után fizetett és a belföldi szereplők külföldre nyújtott hiteleire és hitelviszonyt megtestesítő értékpapír-befektetéseire kapott adósságszolgálat egyenlege;

- folyó transzfer: a fizetésimérleg-statisztikában egyéb elsődleges jövedelem néven megjelenő tétel legjelentősebb részét az Európai Uniótól kapott agrártámogatások teszik ki - emellett itt jelennek meg a termék- és termelési adók, illetve támogatások és a bérleti díjakból származó jövedelmek.

\footnotetext{
${ }^{2}$ Az egyéb elsődleges jövedelmek között szereplő folyó viszonzatlan átutalásokat.
} 
A GNI-mutatóban a GDP-t korrigáló tényezők - a jövedelmek és a folyó transzferek közül a tőkejövedelmek (kamat és FDI) szerepe hangsúlyosabb. Ennek oka egyrészt, hogy a folyó transzferekhez képest nagyobb volumenúek, másrészt termeléshez köthetően jöttek létre, így több hasznos információt hordoznak egy ország gazdasági helyzetét illetően.

\section{A GDP és GNI eltérése Magyarországon}

\subsection{A GDP-GNI rés alakulása}

2016-ban a GNI reálnövekedése jelentősen meghaladta a GDP bövülését - így a GNI reálnövekedése elérte a válság elött jellemző szintet. 2013-ig a GDP és a GNI éves reálnövekedése közötti különbség nem volt számottevő, ami azt jelentette, hogy a rezidens és a Magyarországon tevékenykedő nem rezidens gazdasági szereplők reáljövedelmének bővülési üteme hasonló volt. Az elmúlt években ugyanakkor a két mutató eltérően alakult: a GNI reálnövekedése dinamikusan emelkedett, miközben a GDP növekedési üteme fokozatosan mérséklődött. Ennek eredményeként 2016ban a GNI reálnövekedése (a GDP-növekedést mintegy 2 százalékponttal meghaladva) 4,3 százalékot tett ki, így a GNI bővülése elérte a válság előtt jellemző szintet (1. ábra).

\section{1. ábra}

A GDP és GNI éves reálnövekedése

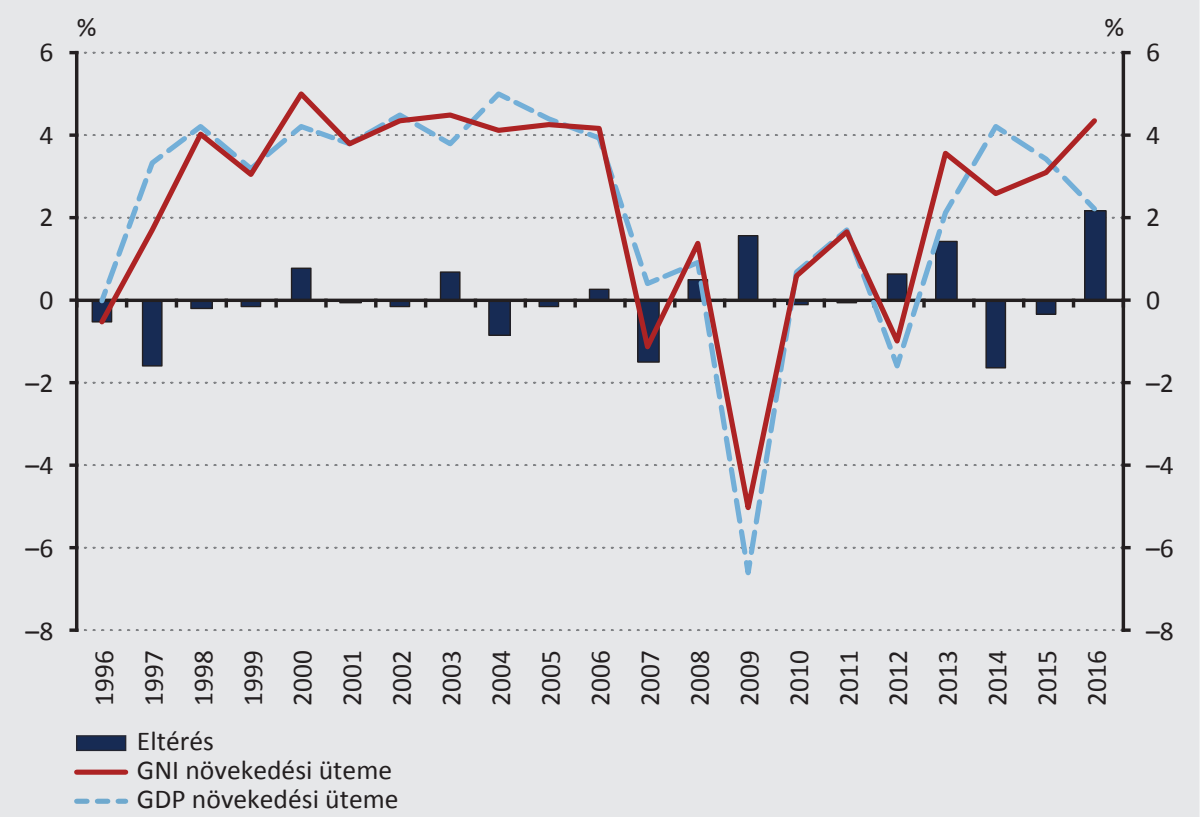

Megjegyzés: 2008-ban módszertani váltás történt az FDI-jövedelem elszámolásában (bővebben lásd: 2. Függelék).

Forrás: KSH (2018) 
A válság elötti időszakban a GDP-GNI közötti eltérés viszonylag stabilan, a GDP 4-6 százaléka között alakult. Az 1990-es évek vége és 2006 közötti stabil GDP-GNI rés időszakában a külföldi vállalatok profitja játszott kulcsszerepet. A 2000-es évek közepén - az Európai Unióhoz való csatlakozás következtében - a jelentősen emelkedő munkavállalói jövedelmek és a GNI szempontjából releváns beáramló transzferek egyaránt hozzájárultak a GDP-GNI rés kismértékú csökkenéséhez. A válságot megelőző években ugyanakkor a részesedésekhez kapcsolódó jövedelmek, valamint a külföldre fizetett kamatkiadások egyidejü bővülése miatt a GDP-GNI közötti eltérés historikus csúcsra, a GDP 6 százaléka fölé nőtt. A válság éveiben, a gyorsan emelkedő adósságállomány után külföldre fizetett kamatkiadások tovább emelkedtek, ami a GDP-GNI rés bővülésének irányába hatott, ugyanakkor ezt a hatást több mint ellensúlyozta a nem rezidens vállalatok visszaeső profitja, és az EU-ból származó folyó transzfer emelkedése.

A válságot követően a dinamikusan bövülő munkavállalói jövedelmek és a mérlegalkalmazkodás következtében mérséklödő kamatkiadások eredményeként a GDP-GNI különbség trendszerüen mérséklődött. A rés csökkenését enyhén fékezte a külföldi

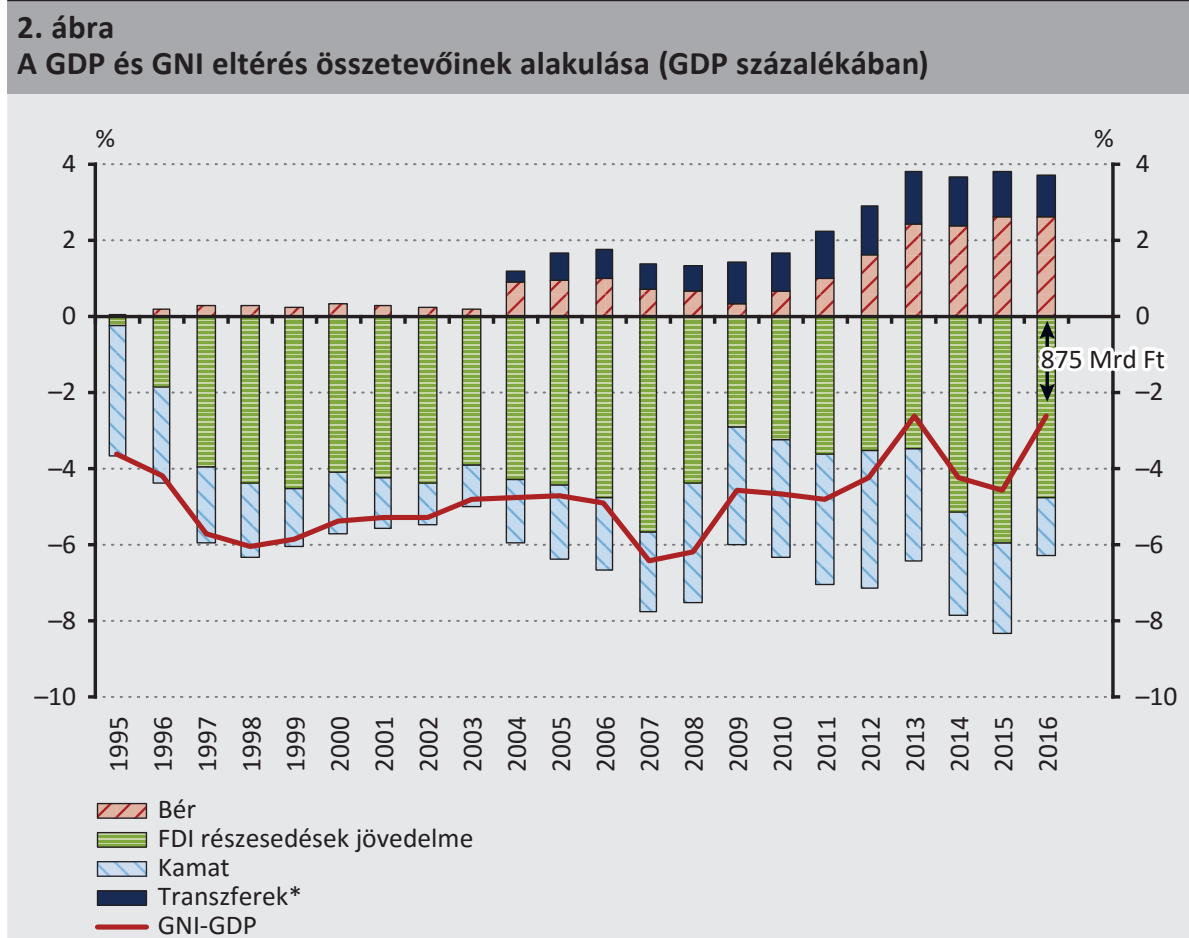

Megjegyzés: 2008-ban módszertani váltás történt az FDI-jövedelem elszámolásában (bővebben lásd: 2. Függelék).

*Az egyéb elsődleges jövedelmek között szereplö transzferek

Forrás: KSH (2018), MNB (2018) 
vállalatok profitjának növekedése, ami a válság előtt tapasztalt szint közelébe emelkedett. 2014-2015-ben egy multinacionális vállalat egyedi tételéhez kapcsolódóan a Magyarországon múködő külföldi vállalatok profitja jelentősen megnőtt, ami a GDP-GNI közötti különbség megugrásához vezetett (MNB 2016b). Ezt követően, 2016-ban a korábban a rés növekedését befolyásoló ágazatban nagyobb mértékü profitcsökkenés történt (MNB 2017c), így a GDP 2,4 százalékára szűkült a rés. A csökkenést érdemben támogatta a bruttó külső adósság állományának és implicit kamatának mérséklődése mellett csökkenő kamatkiadások, valamint a vállalati profitok - az előző évi kiugró értéknél - mérsékeltebb szintje (2. ábra).

\subsection{Mely ágazatokhoz köthető a FDI-jövedelmek kiáramlása?}

A GDP és GNI közötti eltérést föként a feldolgozóipar (autó- és gyógyszeripar), valamint az egyéb kiegészitő üzleti szolgáltatások jövedelme határozta meg. A GNI és GDP közötti jövedelemáramlásokat alapvetően határozza meg a külföldi tulajdonban lévő vállalatok jövedelme. Ez a jövedelem a Magyarországon múködő (a befektetések egyenlegét tekintve a GDP közel 50 százalékát kitevő) közvetlentőke-befektetések normál üzletmenet szerinti eredménye. Ez a mutató a vállalatok teljes nyereségét tartalmazza, amit a vállalatok később kifizethetnek osztalékként a tulajdonos részére, vagy újra befektethetik a magyar gazdaságban. Fontos ugyanakkor felhívni a figyelmet, hogy - ahogyan arra Balatoni - Pitz (2012) tanulmányukban rámutatnak - a múködőtőke növekedési hatása jelentős, így annak ellenére, hogy a múködőtőke implicit hozama meghaladta az alternatív finanszírozási forrásokét, a bruttó nemzeti jövedelemre gyakorolt hatása összességében lehet pozitiv.

Az FDI-jövedelem közel fele a feldolgozóipari ágazatokhoz kötődik (3. ábra). Az ágazat nyereségében szerepe volt többek között a járműgyártás emelkedő jövedelmének - a megépülő új gyárakhoz és felfutó termeléshez köthetően -, valamint a gyógyszergyártás és az elektronikai termékek gyártásához kapcsolódó iparágak növekvő nyereségének is. Emellett a külföldi vállalatok jövedelmének dinamikáját 2014 és 2016 között jelentősen befolyásolta az egyéb kiegészítő üzleti szolgáltatások ágazat jövedelme. Ez jelentős részben egy Magyarországon múködő multinacionális vállalathoz köthető, amelynek nyeresége 2014-2015 során jelentősen emelkedett, majd 2016-ban visszaesett, és ami az FDI-jövedelmek egyenlegét is jelentősen befolyásolta (MNB 2016b). 


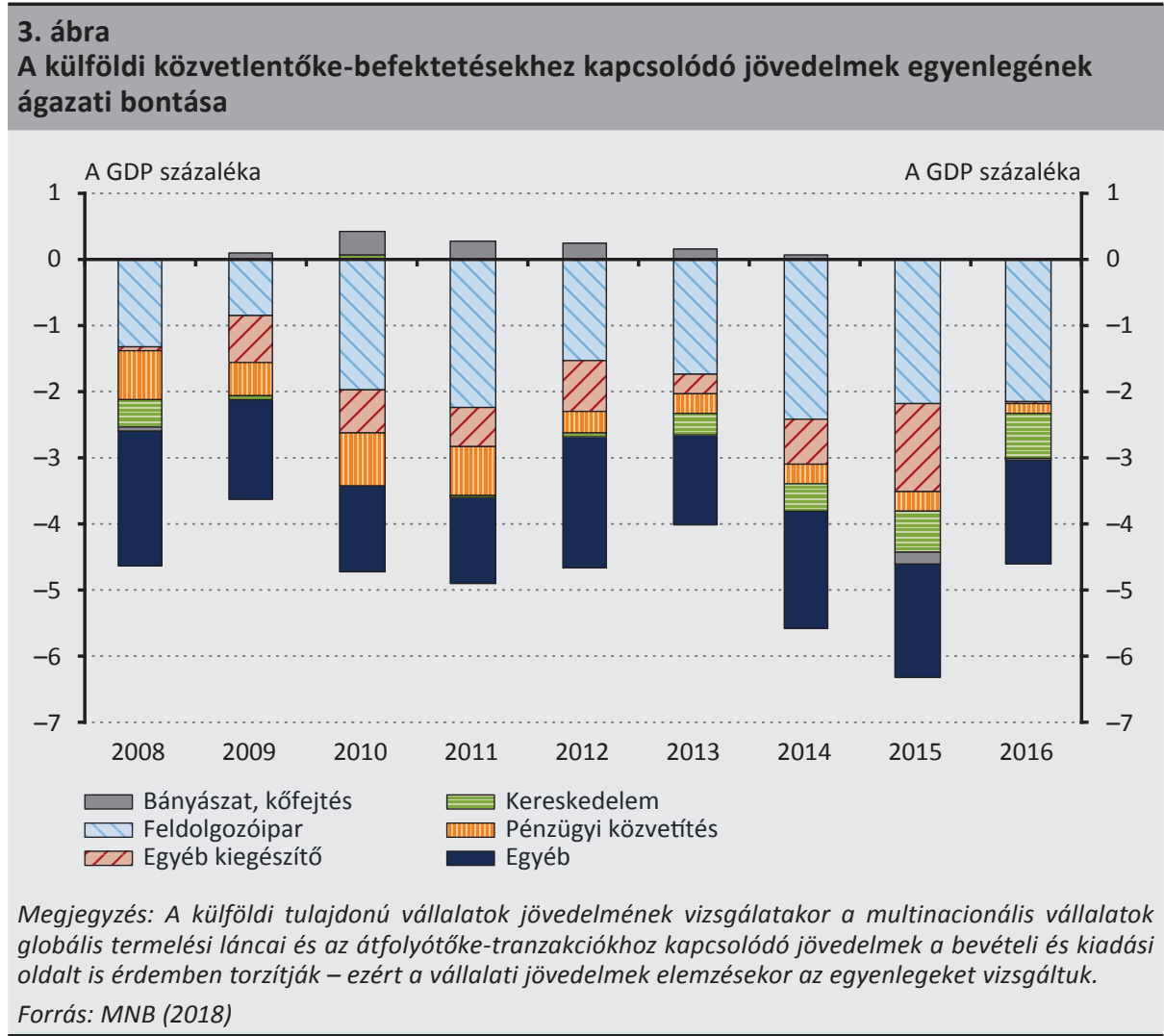

\subsection{Melyik országok felé történt jövedelemkiáramlás?}

A GDP-GNI rést meghatározó közvetlentőke-befektetések jövedelmei - a befektetések forrásországainak megfelelően - föként az eurozóna magországaiba áramlanak. A GDP és GNI közötti különbséget meghatározza a közvetlentőke-befektetések jövedelme. Mivel Magyarországon a közvetlentőke-befeketések jelentős része közvetlenül az EU magországaiból érkezik, a jövedelem nagyobb részét is ezen országok leányvállalatai termelik. 2011-ig a hazai FDI-állomány legfontosabb forrásországának számító Németországba áramlott a legtöbb FDI-jövedelem (4. ábra). Ezt követően az Ausztriába és Hollandiába áramló jövedelmek bővültek jelentősen - a holland vállalatok esetében ugyanakkor vélhetően nem ez az ország a tőke végső forrása (vállalatszervezési és adózási okokból több multinacionális vállalat is Hollandiára köztes állomásként tekint). A holland és osztrák közvetlentőke-befektetések jövedelmeit részben a német befektetések is magyarázzák (részletesebben lásd: MNB 2016a). 


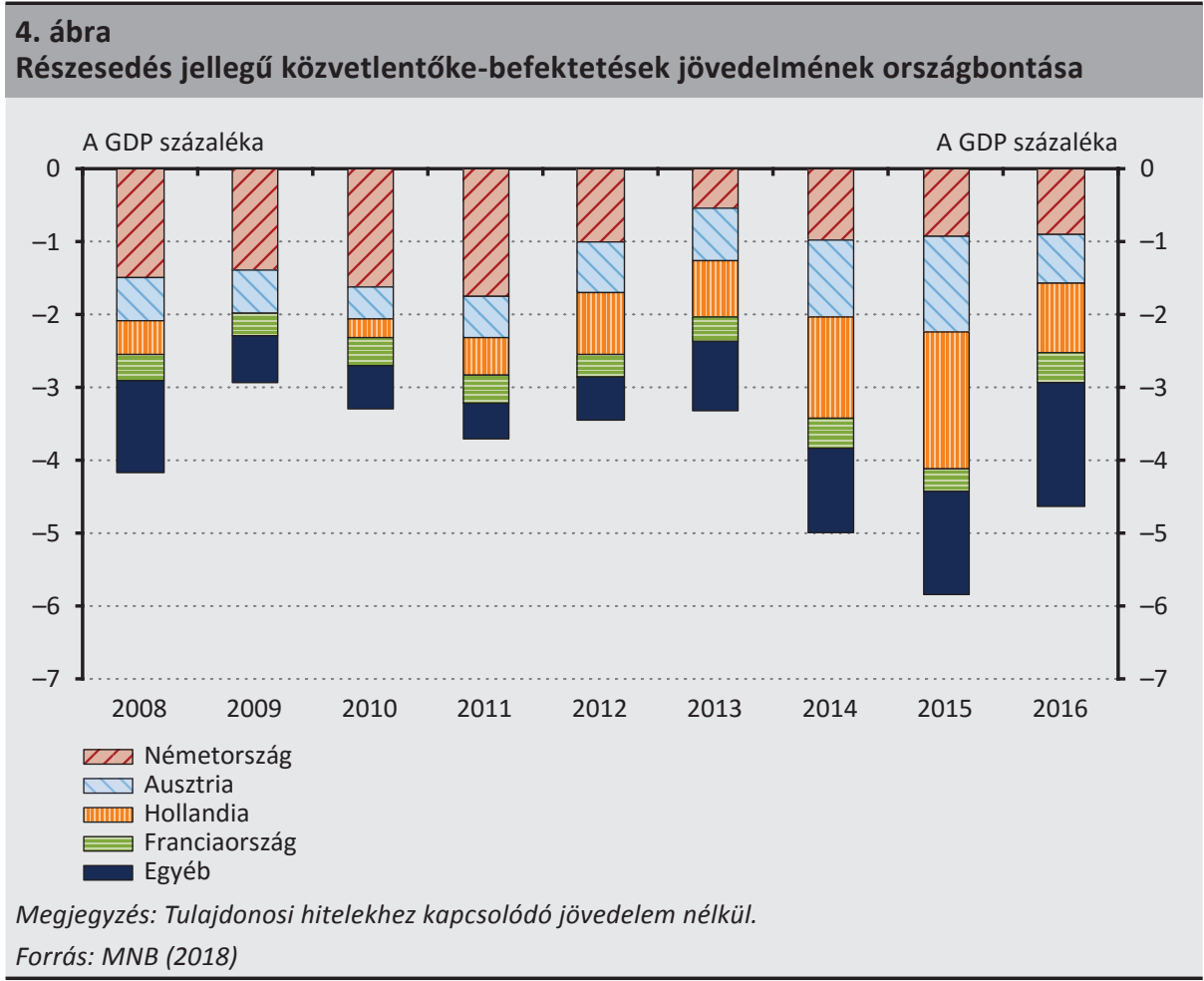

A GNI-t alkotó jövedelmek egyenlegét országbontásban vizsgálva a külföldön átmenetileg munkát vállalók jövedelmei miatt a német ajkú országokkal kapcsolatos jövedelemáramlások növelik a magyar GNI-t, míg az Egyesült Államok szerepe az államadósság finanszírozásához kapcsolódóan magasabb (5. ábra). A GNI és GDP közötti különbség országbontását tekintve (az általunk általában folyó transzferek között elszámolt egyéb elsődleges jövedelmeket ${ }^{3}$ figyelmen kívül hagyva) a közvetlentőke-befektetések jövedelmétől eltérő dinamikát figyelhetünk meg. 2012 előtt a Németországgal és Ausztriával kapcsolatos egyenleg csökkentette a GNI-t, 2012ben azonban, a külföldi munkavállalás német szabályozásának lazulásával és így a munkavállalói jövedelmek emelkedésével érdemben lecsökkent a Németországba és Ausztriába utalt jövedelmek mértéke. Ezzel kapcsolatban fontos megjegyezni, hogy bár a munkabér növeli a magyar GNI értékét, ez nem kerül teljes mértékben hazautalásra, hiszen tartalmazza az adókat és az átmenetileg külföldön élők fogyasztását is (Csortos - Kóczián 2017).

\footnotetext{
${ }^{3}$ Ezeket nem vizsgáljuk, mivel bontásuk nem összeegyeztethető a többi jövedelem országbontásával, ezek a jövedelemáramlások az EU intézményeivel szemben valósulnak meg.
} 
Hollandia szerepe a teljes jövedelmek között is kiemelkedő, miközben az Egyesült Államokba és Luxemburgba utalt jövedelmek mérséklődést mutatnak 2013 és 2016 között. Ebben szerepe lehet annak, hogy az elmúlt években a lakossági és banki finanszírozás erősödésének köszönhetően mérséklődött a külföldiek állampapír-állománya, valamint annak, hogy az alacsonyabb kamatok hatására is mérséklődött az állam kamatkiadása.

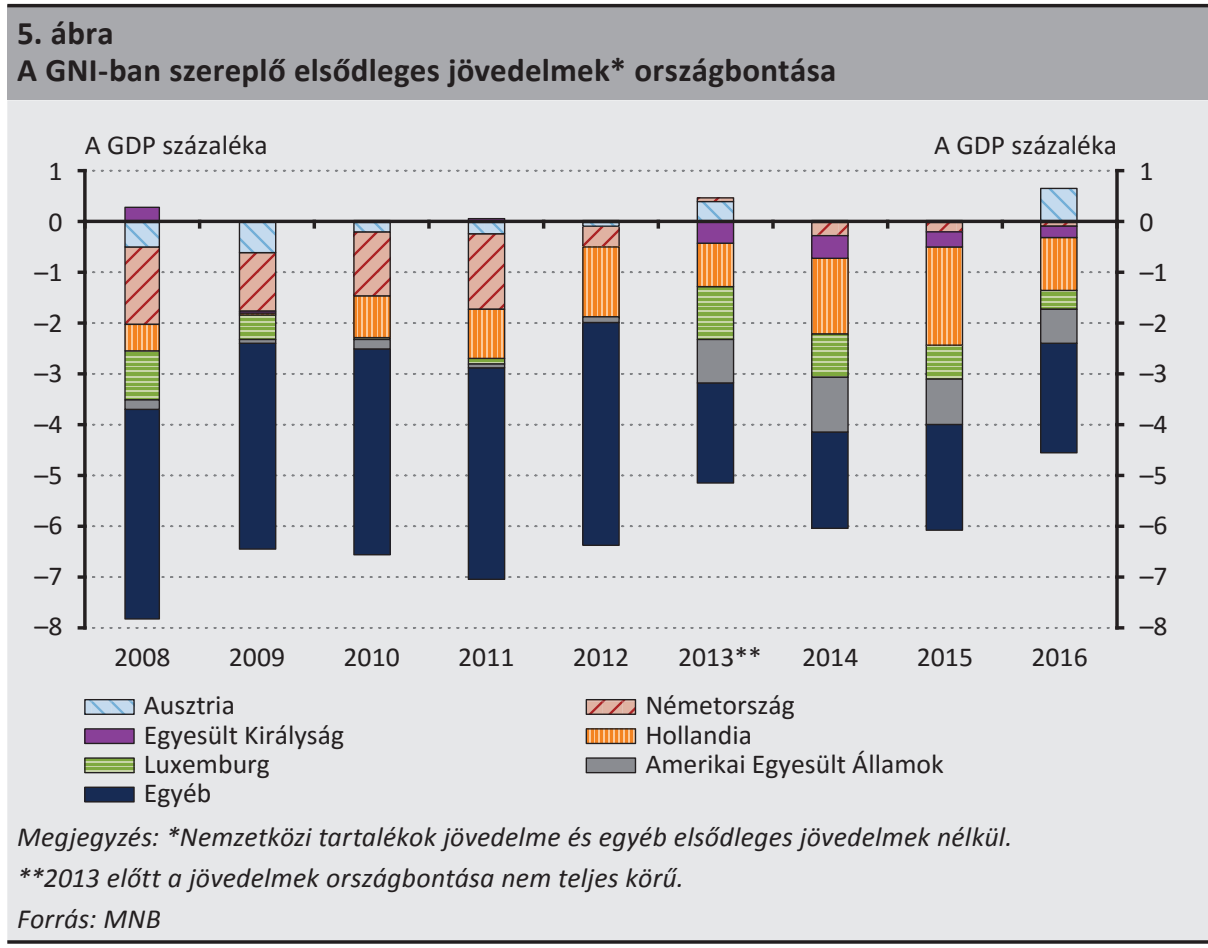

\subsection{A szektorok jövedelmének alakulása}

A GDP-GNI rés a válság kitörése óta fokozatosan csökkent, azaz a belföldi szereplők jövedelme kevesebbel marad el a belföldön megtermelt jövedelem értékétöl $(G D P)$, mint 10 évvel korábban. Ahogy az előző részekben rámutattunk, a 2007-es „csúcsot” követően a GDP-GNI rés mérséklődni kezdett, aminek eredményeként az 2016-ra 875 milliárd forintra csökkent. A GDP és GNI közötti eltérés szükülése azt jelenti, hogy 2016-ban a megtermelt jövedelemből a korábban jellemzőnél több marad a belföldi szereplőknél, és kevesebb áramlik külföldre. Az alábbiakban arra a kérdésre keressük a választ, hogyan oszlik meg a megtermelt jövedelem a belföldi szektorok között, illetve ezzel összefüggésben, hogy az utóbbi évek kisebb mértékű külföldi jövedelemkiáramlása melyik hazai szektor jövedelmét gyarapította. A szektorális bontást vizsgálva (6. ábra) látható, hogy a belföldi szektorok közül a leginkább a vállalati és állami GNI bővült, miközben a háztartások GDP-arányos elsődleges jövedelme trendszerǔen mérséklődött. 


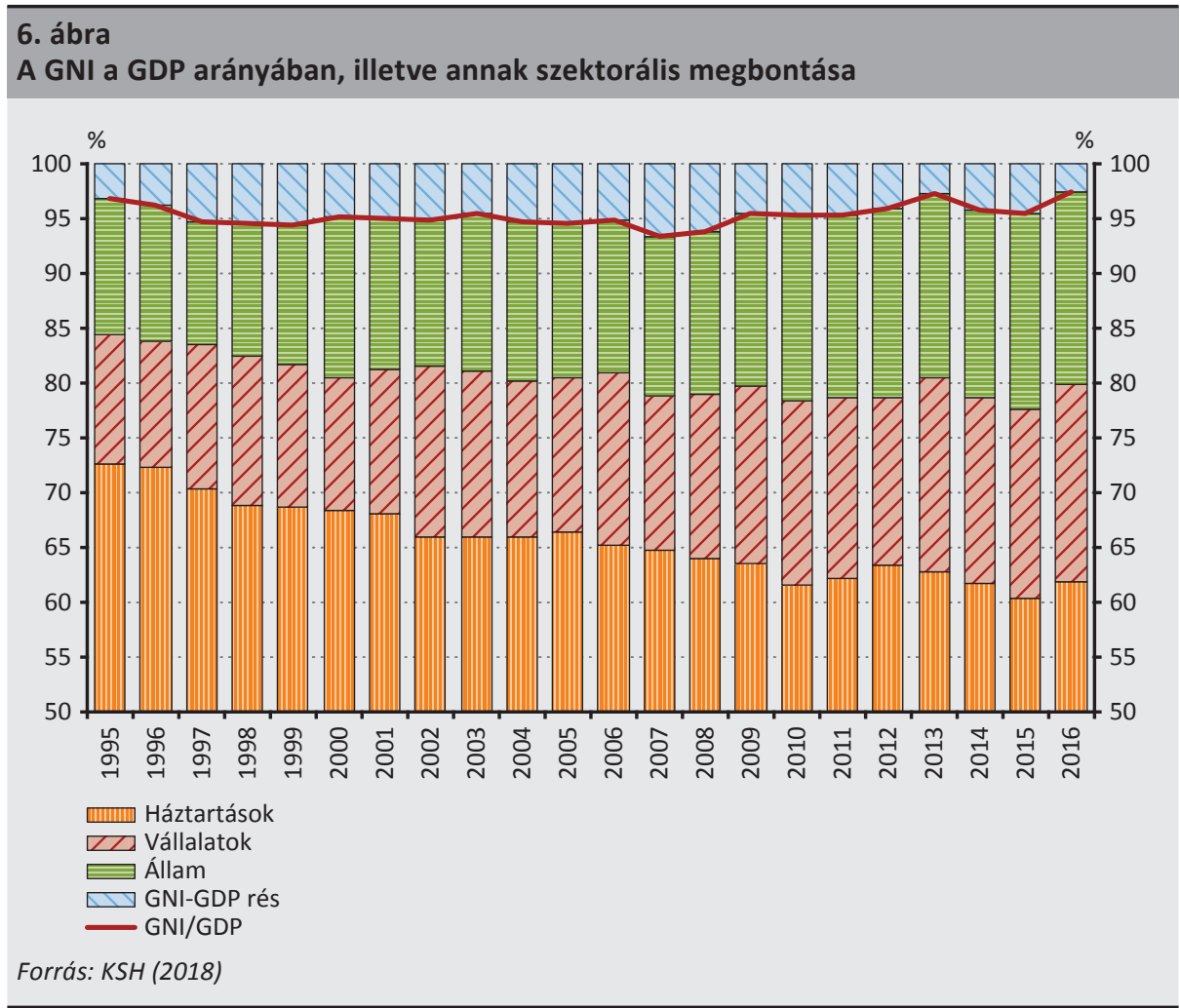

A háztartások részesedése a GNI-ból folyamatosan csökkent, ami legnagyobb részben a munkavállalói jövedelmek részarányának mérséklödésével magyarázható (7. ábra). A lakossági GNI 1995-ről 2007-re 7,7 százalékponttal, ezt követően 2016-ra további közel 3 százalékponttal csökkent. A dekompozícióból látható, hogy az 1995 óta tartó részaránycsökkenés érdemi része a munkavállalói jövedelmek arányának közel 6 százalékpontos mérséklődéséhez köthető, amely mellett a tulajdonosi jövedelmek és a háztartások múködési eredményének részaránya is mintegy 2-2 százalékponttal alacsonyabb lett. A munkavállalói jövedelmek GDP-arányos értékének csökkenése párhuzamba állítható a bérhányad globálisan tapasztalható mérséklődésével (MNB 2017b). Az, hogy ez valóban csökkenti-e a nemzetgazdaság GDP-arányos bruttó nemzeti jövedelmét, attól függ, hogy az adott háztartást foglalkoztató vállalat belföldi vagy külföldi. Abban az esetben, ha a külföldi vállalatok profitálnak a háztartások munkavállalói jövedelmének mérséklődéséből, akkor a GNI csökken, amivel párhuzamosan a GDP-GNI rés emelkedik - ami szerepet játszott az 1995-2007 között lezajlott folyamatokban. Abban az esetben viszont, ha ez a jövedelem belföldi vállalatoknál jelenik meg, a múködési eredmény bővülésében, akkor összességében a GNI nem változik, csak annak szektorális megoszlása - ez történt 2007-et követően. A tulajdonosi jövedelmek részarányának mérséklődéséből 
jelentős rész - az alacsony kamatkörnyezethez és a nyugdíjrendszer átalakításához köthető - csökkenő kamatjövedelmekkel magyarázható, a müködési eredmény pedig a saját lakás szolgáltatás értékét tartalmazza, amelynek alakulását a lakáspiaci árak érdemben befolyásolják.

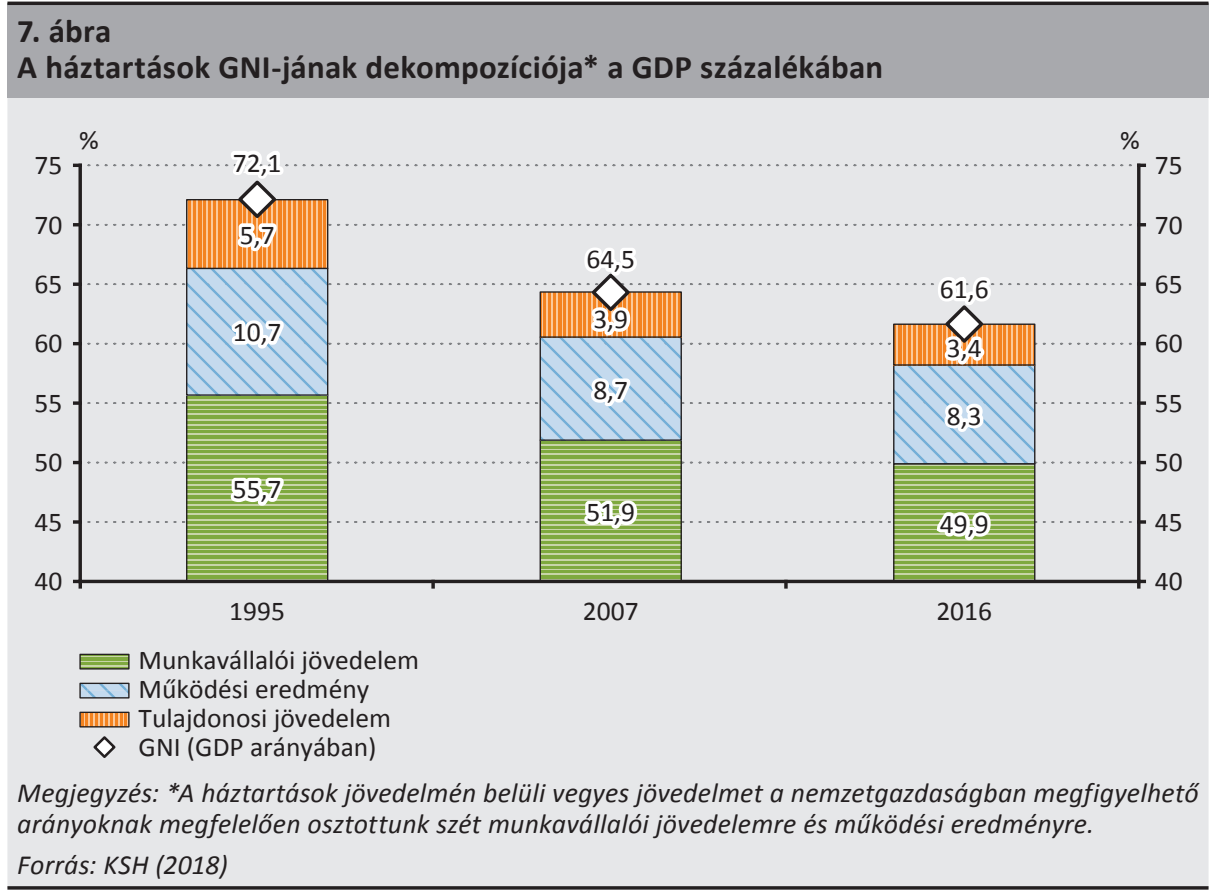

Az állam GDP-arányos GNI-ja a 2001-es 13,94 százalékról 2016-ra 17,6 százalékra emelkedett, ami elsősorban a fogyasztási adók növekedésével hozható összefüggésbe (8. ábra). Az állam elsődleges jövedelmének meghatározó részét a fogyasztási adók (áfa, jövedéki adó) teszik ki, amelyek 2006-ig csökkentek, majd ezt követően jelentős emelkedésnek indultak. A fogyasztási adókból származó bevétel emelkedése mellett az állam jövedelmét a különböző különadók bevezetése is növelte (például közműadó, reklámadó, pénzügyi tranzakciós illeték, távközlési adó stb). Végül az állam kamatkiadásainak csökkenése is támogatta az elsődleges jövedelem bővülését. 


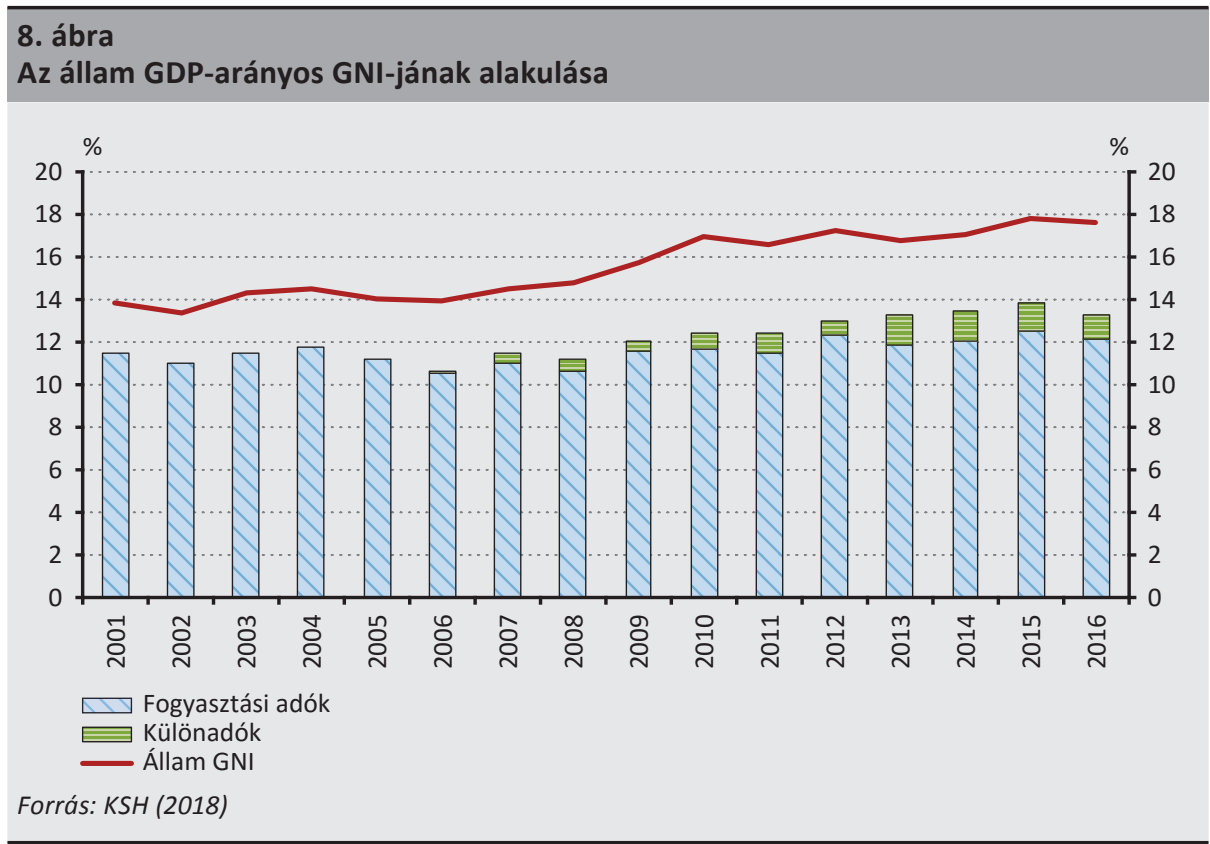

A vállalatok GDP-arányos elsődleges jövedelmének válságot követő emelkedése döntően a müködési eredmény növekedésével magyarázható, amihez a KKV-k nagyobb, a nagyvállalatok kisebb mértékben járultak hozzá (9. ábra). A vállalati GNI-t a múködési eredmény és a tulajdonosi jövedelem alkotja - utóbbi a belföldi és külföldi tulajdonosok felé történő profitkifizetést és a nettó kamatkiadásokat tartalmazza. A különböző méretű vállalatok múködési eredménye a pénzügyi válság kitöréséig hasonló mértékben emelkedett. A válság kitörését követő években a KKV-k jövedelme érdemben visszaesett, míg a nagyvállalatok működési eredménye enyhén tovább emelkedett. 2012-t követően a KKV-k jövedelmének dinamikus növekedése meghaladta a nagyvállalatoknál tapasztaltat, ugyanakkor az alszektor bruttó múködési eredménye továbbra is elmarad a nagyvállalatokétól. ${ }^{4} \mathrm{~A}$ vállalati szektor jövedelmének elmúlt évekbeli emelkedése összefüggésbe hozható azzal, hogy a háztartások csökkenő munkavállalói jövedelme a hazai vállalatoknál a múködési eredmény emelkedésében jelenik meg, miközben az olajáresés miatti cserearány-javulás is jelentősen javította a szektor jövedelmezőségét. A vállalatok tulajdonosi jövedelme 2008 óta a GDP 6-8 százalékával csökkentette a szektor GNIját, amiben a válságot követően meghatározó szerepet játszott a kamatkiadások mérlegalkalmazkodáshoz köthető mérséklődése (a 2014-2015-ös emelkedés inkább egyedi tényezőknek volt köszönhető).

\footnotetext{
${ }^{4}$ Érdemes továbbá azt is szem előtt tartani, hogy a vállalatok GDP-arányos múködési eredménye 2015-ben a nagyvállalatok esetében mintegy 1500 , míg a KKV-k esetében több mint 400000 vállalat között oszlott meg - így jelentős különbségek lehetnek az „egy vállalatra eső” jövedelemben.
} 


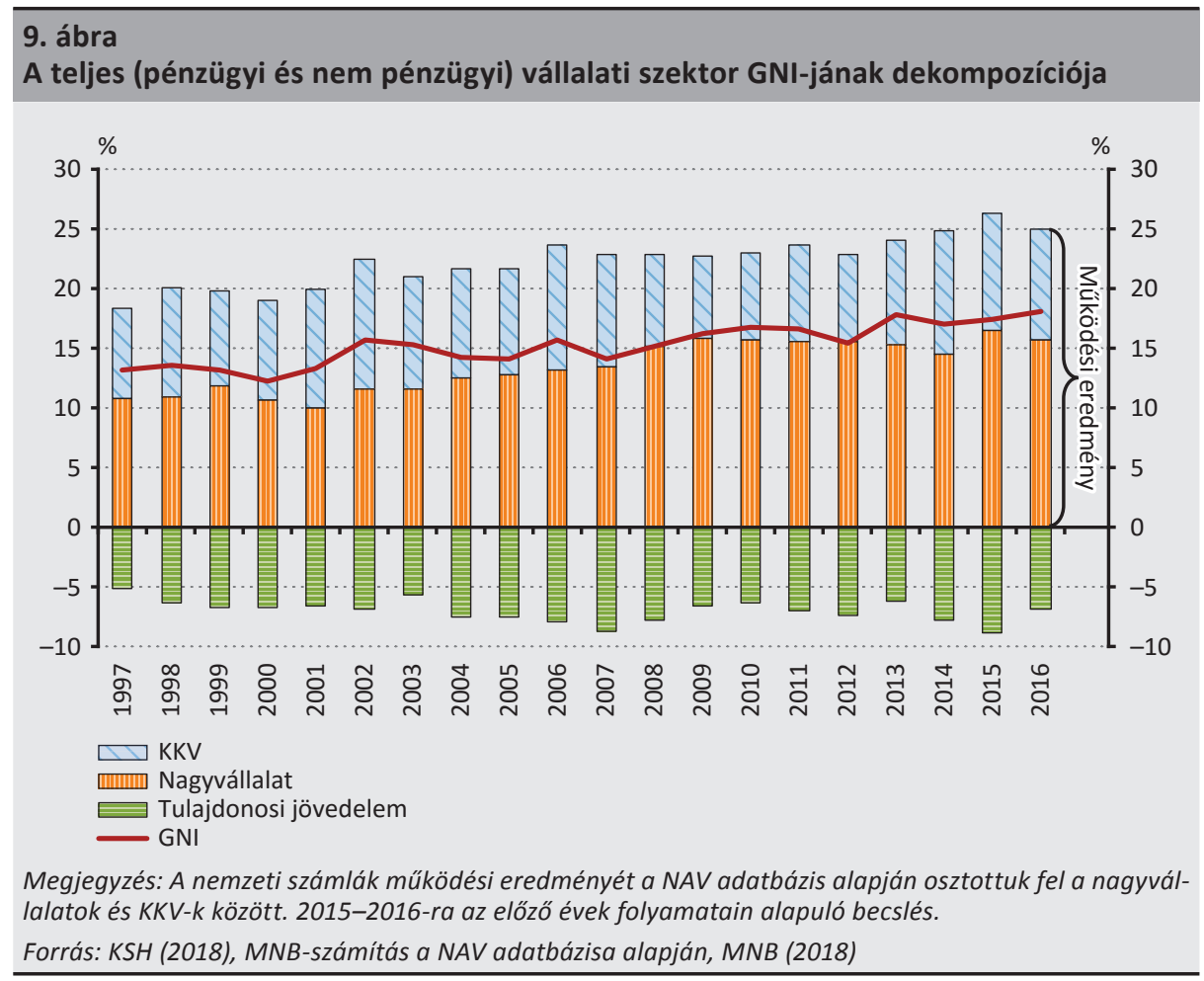

\section{Nemzetközi kitekintés}

A válság előtt régiós összevetésben magas magyar GDP-GNI rés ez elmúlt években jelentősen csökkent, és ma már az egyik legalacsonyabb a régióban (10. ábra). A magas külső tartozásállománnyal összefüggésben a jövedelemkiáramlás Magyarországon és Csehországban volt a legmagasabb a válság előtti években. Míg azonban Csehországban szinte csak a külföldi vállalatokhoz volt köthető a jövedelemkiáramlás, Magyarországon a profit mellett a növekvő bruttó külső adósság kamatterhei is növelték a jövedelemegyenleg hiányát. Bár a válság kitörését követően jelentősen visszaesett a külföldi vállalatok profitja, a növekvő kamatkiadások elsősorban Magyarországon tartották magasan a GDP-GNI rést. A mélypontot követően a régióban általánosan megfigyelhető, hogy a részesedésekhez kapcsolódó jövedelemkiáramlás a vállalati profit emelkedésével összhangban - Szlovákiában és Magyarországon nagyobb volatilitás mellett - növekedett. Az elmúlt években egyre csökkenő kamatkiadások mellett a munkavállalói és a transzferjövedelmek ${ }^{5}$ egyenlege mindegyik régiós országban pozitívan járult hozzá a jövedelmek emelkedéséhez, de leginkább hazánkban csökkentette a GNI és GDP közötti különbséget.

\footnotetext{
${ }^{5}$ Egyéb elsődleges jövedelmek között elszámolt transzferek.
} 


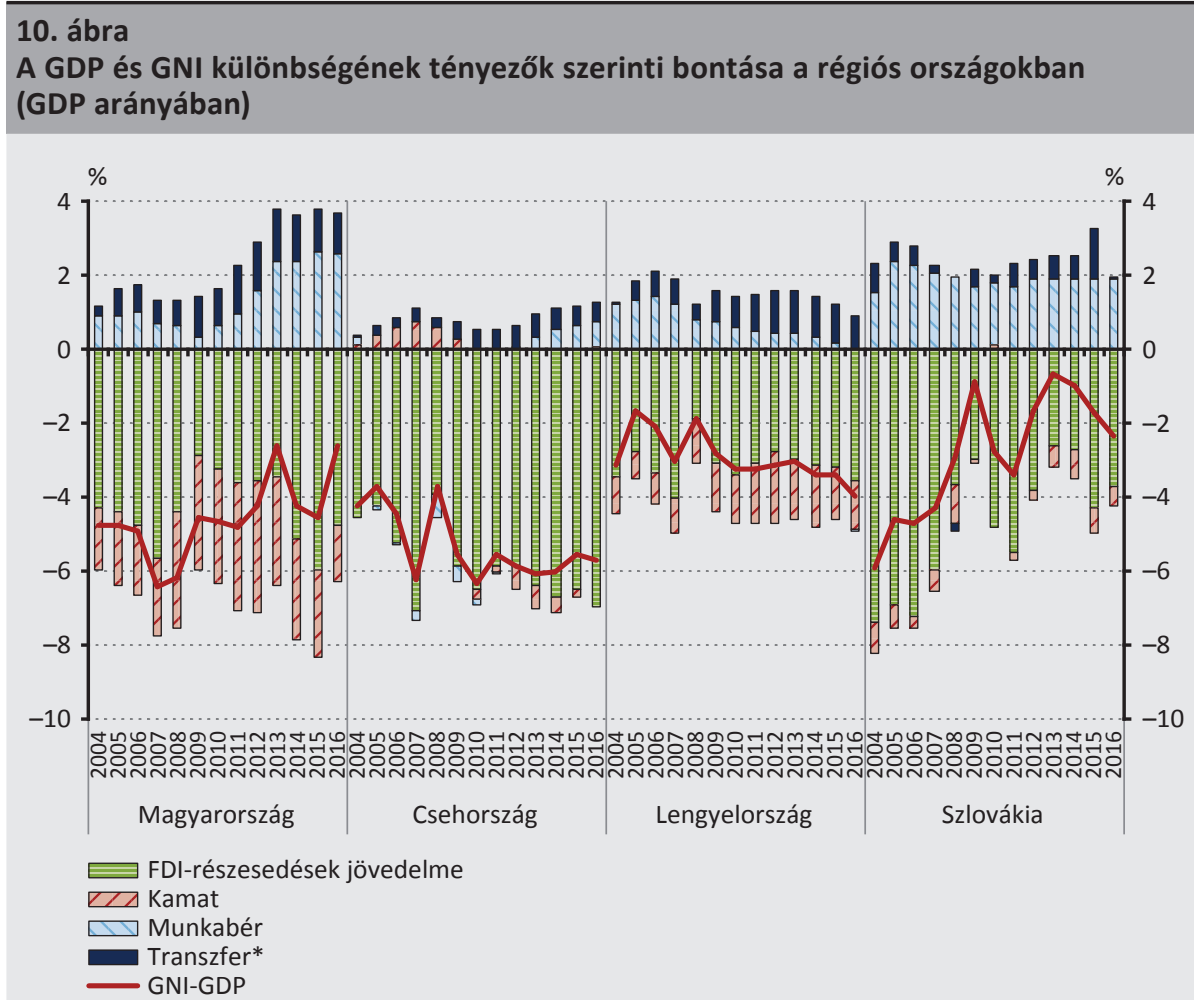

Megjegyzés: 2008-ban módszertani váltás történt a magyar FDI-jövedelem elszámolásában (bővebben lásd: 2. Függelék).

*Az egyéb elsődleges jövedelmek között szereplő transzferek.

Forrás: Eurostat (2018)

Magyarországon az FDI-típusú források utáni jövedelemkiáramlások hátterében elsősorban magas FDI-állomány áll, miközben a müködőtőke implicit hozama elmarad a régiós szinttől (11. ábra). A válság előtt hazánkban a közvetlentőke-befektetések a GDP 50 százaléka körül alakultak, ami érdemben meghaladta a régiós átlagot. Ezzel szemben az FDI-befektetések implicit hozama Magyarországon elmaradt a környező országokban tapasztalt 12-14 százalék közötti értéktől. A válságot követő időszakra is jellemző, hogy a tôkeimport költsége - Szlovákia mellett - hazánkban a legalacsonyabb, miközben a régió legmagasabb bruttó FDI-állományával rendelkezünk. Míg Magyarországon a magas FDI-típusú jövedelemkiáramlás elsősorban a magas FDI-állománynak tudható be, addig Csehországban az állomány mellett a múködőtőke megtérülési rátája is jelentős. A régiós országok közül Lengyelországban a legalacsonyabb a GDP-arányos bruttó FDI-állomány, ami a magas implicit hozam ellenére nem jár jelentős FDI-típusú jövedelemkiáramlással. 


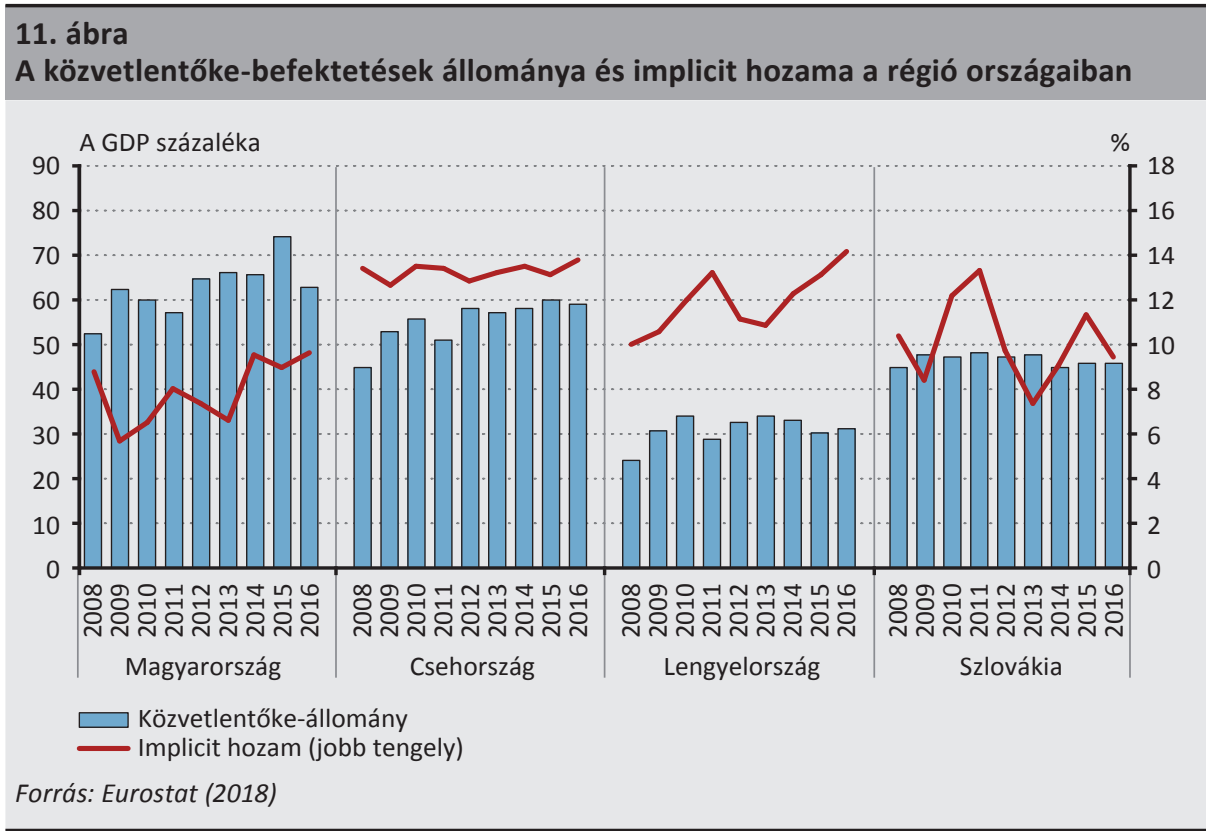

A háztartások GDP-arányos jövedelme eltérö mértékben, de minden régiós államban mérséklödött, míg a vállalatok és az állam jövedelme elsősorban Magyarországon és Lengyelországban emelkedett (12. ábra). 1995 óta a magyar és lengyel háztartások GDP-arányos jövedelme mintegy 10 százalékponttal csökkent, ami mögött elsősorban a bérhányad mérséklődése állt, de az elmúlt pár évben emellett jelentős hatása volt a kamatjövedelmek mérséklődésének is. Az állam GDP-arányos jövedelmének a bővülése elsősorban Magyarországon volt jellemző, aminek mozgatórugóit a korábbiakban már bemutattuk. A vállalatok GDP-arányos jövedelme - a háztartásokkal ellentétes irányú változással - Magyarországon és Lengyelországban mintegy 5 százalékponttal növekedett. A vállalkozások jövedelmének GDP-n belüli súlyának a növekedése a javuló jövedelmezőséggel hozható összefüggésbe. A folyamatok eredményeként az elmúlt húsz évben a GDP-GNI rés Magyarországon érdemben szűkült, míg a régiós versenytársaknál némileg kitágult. 


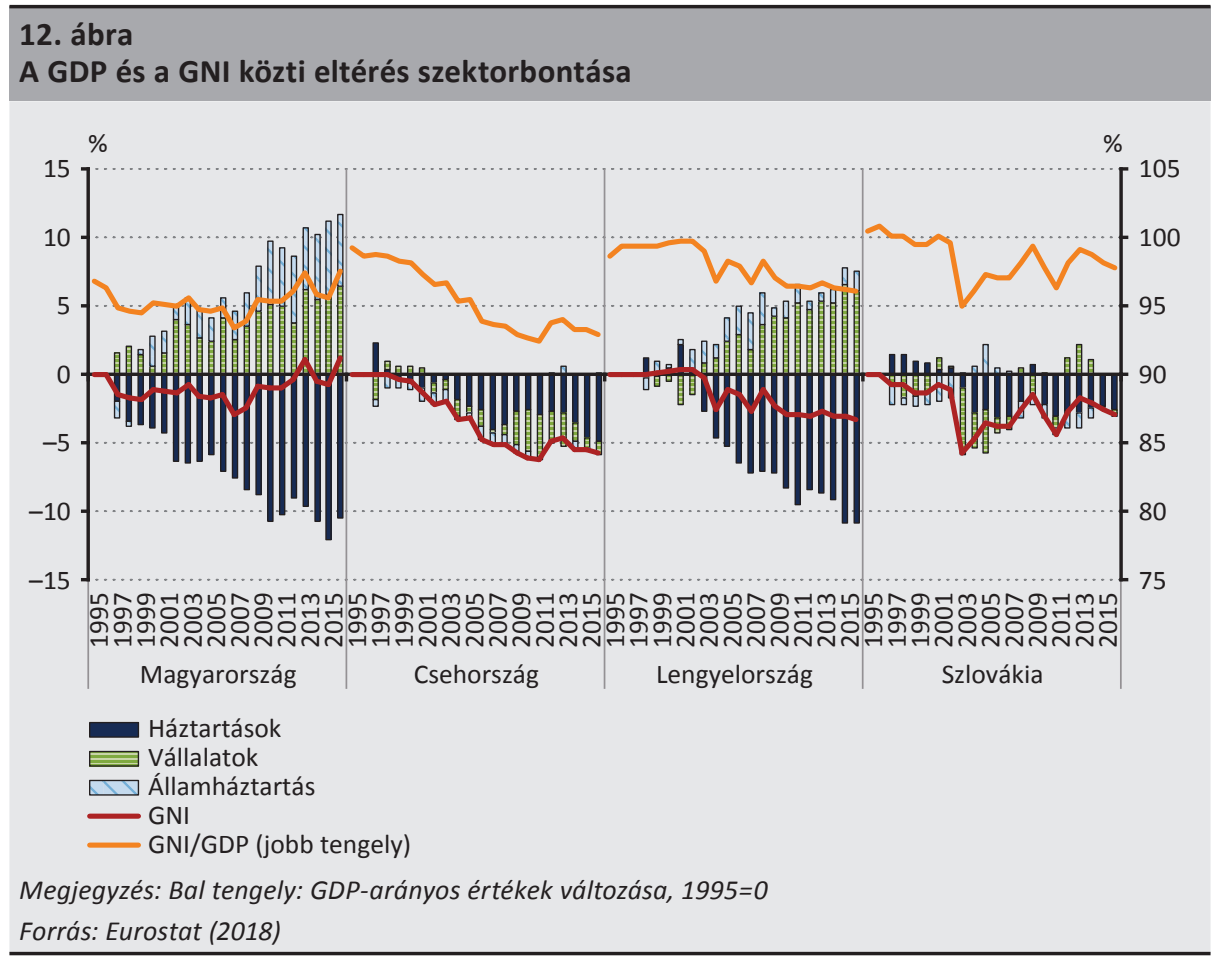

A magyar és a lengyel lakossági GNI csökkenésében szerepet játszhat a bérhányad mérséklődése. A nemzetközi irodalom nagyrészt egyetért abban, hogy a globalizáció, a termékek és szolgáltatások határon átnyúló mozgása csökkenti a bérhányadot. Ennek egyik oka, hogy a magas importigényű ágazatoknak (feldolgozóipar, kereskedelem) alacsonyabb munkaköltséggel termelő országokkal kell versenyeznie az importverseny pedig arra ösztönzi a vállalatokat, hogy tőkeintenzív termelésre álljanak át, csökkentve a bérhányadot. Másrészt a bérhányad csökkenését az is okozhatja, hogy a vállalatok megtermelt jövedelmük kisebb részét fordítják a munkavállalókra, és nagyobb részét osztják fel a tulajdonosok között. A visegrádi országokat tekintve nem mutatható ki egyértelműen ez a kapcsolat. Míg Magyarország és Lengyelország esetében a külkereskedelmi nyitottság - az export és import összege a GDP arányában - emelkedésével csökkent a bérhányad, addig ez Csehországban és Szlovákiában nagyjából szinten maradt a vizsgált időszakban. Ezek a folyamatok tehát nagyban hozzájárulhattak ahhoz, hogy hazánkban és Lengyelországban jóval nagyobb volt a GDP-arányos lakossági GNI csökkenése, mint Csehországban és Szlovákiában. Ugyanakkor figyelemre méltó, hogy annak ellenére, hogy a négy ország közül Lengyelország tekinthető a legzártabb gazdaságnak, itt csökkent a legnagyobb mértékben a bérhányad. A folyamatok eredményeként eltérő nyitottság mellett a bérhányad a régiós országokban 2016-ban hasonló szinten, a GDP 50-55 százaléka között alakult (13. ábra). 


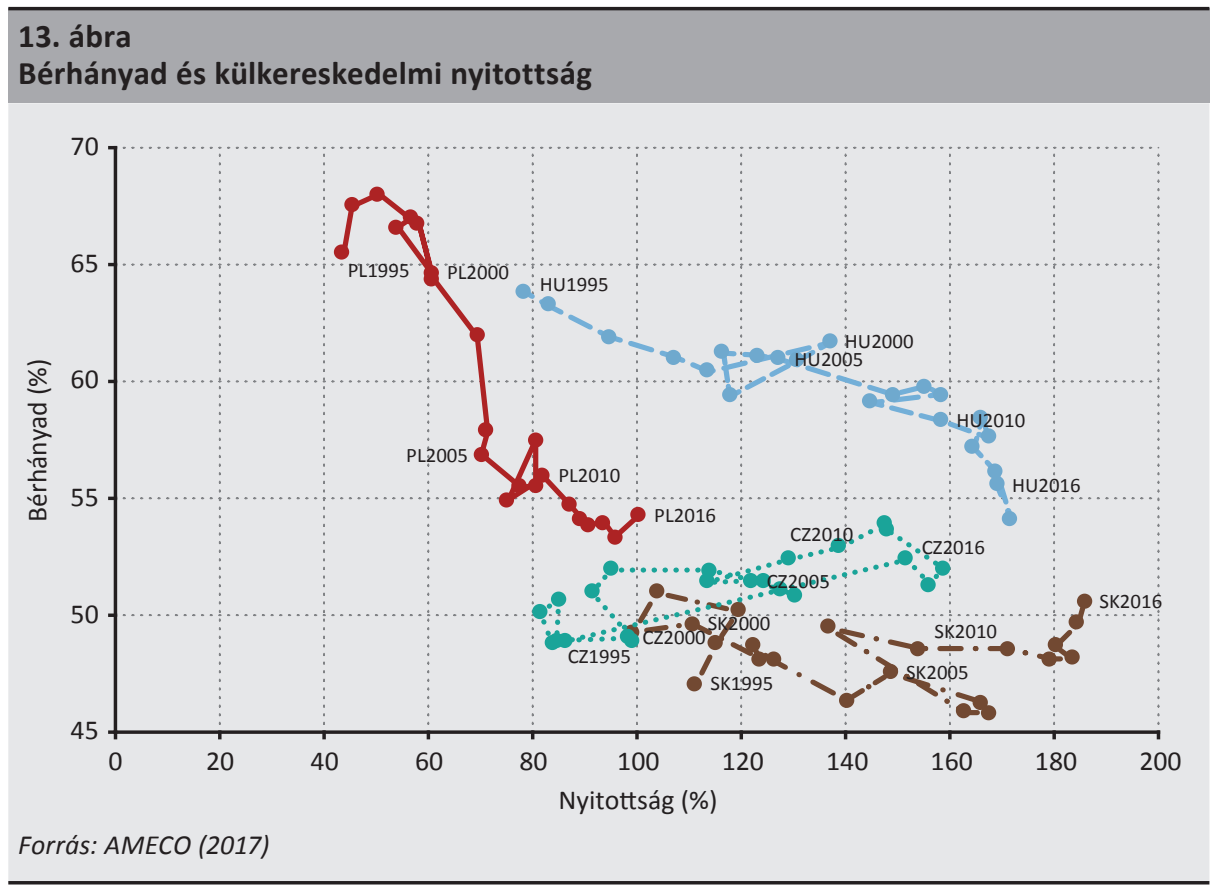

\section{A GDP és GNI közötti eltérés várható alakulása}

\subsection{A GDP-GNI rés az elörejelzési horizonton}

Az elözetes adatok alapján - döntően a külföldi tulajdonú vállalatok profitjának emelkedése miatt - 2017-ben nőtt a GDP és a GNI közötti eltérés. Bár 2017-re vonatkozóan hivatalos adat még nem érhető el, a rendelkezésre álló adatok alapján az elsődleges jövedelmek hiányának emelkedésével a GDP-GNI közötti eltérés is növekedhetett. Az előzetes adatok szerint a külföldi tulajdonú vállalatok profitja - vélhetően a gazdasági növekedés és a társasági adó csökkentésének hatására emelkedett, ami mellett az átmenetileg (1 évnél rövidebb ideig) külföldön munkát vállalók számának enyhe csökkenése miatt a munkavállalói jövedelmek is mérséklődtek. E két hatást némiképp ellensúlyozta a külföldi adósság folytatódó csökkenésének köszönhetően mérséklődő kamatkiadás, ami a GDP-GNI rés csökkenésének irányába hatott. A külföldre fizetett nettó kamatkiadás csökkenését az Inflációs jelentés előrejelzése szerint tovább csökkenő nettó külső adósság és alacsony hozamkörnyezet egyaránt támogatja (MNB 2017a). Az elsődleges jövedelmek között megjelenő folyó EU-transzfer felhasználás - amelynek túlnyomó részét az Európai Uniótól kapott területalapú mezőgazdasági támogatások teszik ki - a következő három évben stabil mértékben javítja a GNI-t. 
Elöretekintve, rövid távon a külföldi tulajdonú vállalatok FDI-jövedelmének emelkedését nagyjából ellensúlyozhatja a nettó kamatkiadás mérséklödése, így a GNI-GDP rés stabilizálódhat (14. ábra). A külföldi tulajdonú vállalatok jövedelemének várható alakulásában meghatározó szerepet játszik az exportteljesítmény. A historikus adatok alapján a közvetlentőke-befektetések jövedelme jelentős együttmozgást mutat a vállalati exportteljesítmény alakulásával (MNB 2017c). Ennek hátterében az áll, hogy a külföldi tulajdonú vállalatok érdemi része föként exportra termel, és ezek a vállalatok jelentős szerepet játszanak a gazdaság exportteljesítményének alakulásában. Ennek megfelelően a közvetlentőke-befeketések jövedelmének várható alakulásában meghatározó szerepet játszik az exportteljesítmény, ami az Inflációs jelentés (MNB 2017a) alapján várhatóan tovább bővül. Ezt a folyamatot ugyanakkor a következő években nagyjából ellensúlyozhatja, hogy - az Inflációs jelentés külső finanszírozási képességre vonatkozó előrejelzése szerint - a csökkenő külső adósság és a kialakult alacsony kamatszintek mellett mérséklődhet a külföldre fizetendő kamatkiadás nagysága.

\section{4. ábra}

A GNI-GDP rés az előrejelzési horizonton (a GDP arányában)

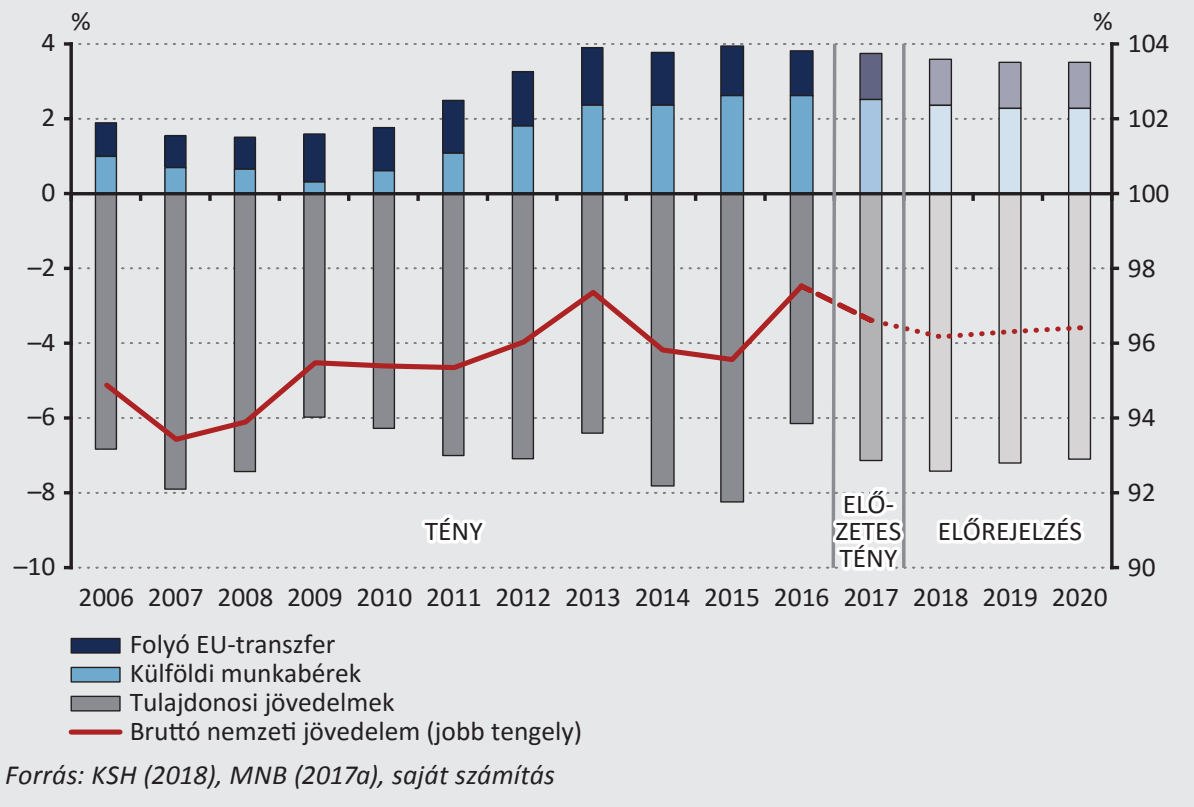




\subsection{A GDP-GNI eltérés hosszú távú alakulása}

A GDP és GNI közötti eltérést hosszú távon a külső tényezők mellett elsősorban a magyar gazdaság finanszírozási szerkezete befolyásolja. A területalapú EU-támogatások hosszabb távon is stabil nettó jövedelembeáramlást jelentenek Magyarország számára, míg a külső adóssághoz kapcsolódó jövedelemkiáramlás - a külső adósság várható csökkenésével párhuzamosan - mérséklődhet. A külföldön munkát vállaló magyarok - gazdaságpolitikai céllal összhangban történő - visszaáramlása a hazai munkaerőpiacra, illetve a Magyarországon dolgozó külföldi munkavállalók jövedelmének - a gazdaság növekvő munkaerőhiánya miatti - emelkedése csökkentheti a nettó bérjövedelem-beáramlást, így a GDP-GNI rés emelkedésének irányába hat. A Magyarországon befektetett közvetlen tőke állománya adottság, amely jelentősen befolyásolja a GDP-GNI rés legnagyobb részét kitevő FDI-jövedelem-kiáramlás nagyságát is. A GDP-GNI rés hosszú távú alakulása jelentősen függ attól, hogy a magyar gazdaság nyugati országokhoz történő felzárkózása milyen finanszírozási szerkezetben valósul meg: amennyiben a gazdasági növekedést támogató beruházások finanszírozása külföldi forrásokból történik, emelkedhet, ha pedig belső megtakarításokból, akkor csökkenhet a GDP-GNI közötti eltérés.

A fejlettség és a GDP-GNI rés alakulása között pozitiv kapcsolat mutatható ki. Európában a magasabb egy főre eső GDP-vel rendelkező országokban jellemzően kisebb a GDP és GNI közötti eltérés - sőt a legmagasabb egy főre eső GDP-vel rendelkező nyugat-európai és skandináv országokban a GNI meg is haladja a GDP-t (15. ábra). Ez elsősorban azzal áll összefüggésben, hogy ezek az országok nettó értelemben külfölddel szembeni hitelezők (Lucas 1990), a nettó FDI-jövedelem-beáramlás pedig növeli a GNI-t. Érdemes megjegyezni, hogy nemcsak pozitív nettó befektetői pozíció esetén, hanem a külföldi követeléseket meghaladó tartozásállomány esetén is elképzelhető pozitív nettó FDI-jövedelem-beáramlás, amennyiben a külföldi követelések hozama érdemben meghaladja a tartozásokra fizetett implicit hozamot. Az előbbi, pozitív elsődleges egyenleggel rendelkező országokkal ellentétben a visegrádi országok és a balti államok - ahol jelentős az FDI-ból történő finanszírozás - nettó hitelfelvevők, ahol nettó jövedelemkiáramlás figyelhető meg. Érdemes kiemelni Csehország helyzetét, ahol a fejlettségéből adódónál jóval nagyobb mértékben marad el a GNI a GDP-től, aminek hátterében elsősorban a külföldi tulajdonú vállalatok magas profitabilitása áll (a nettó kamatkiadás igen alacsony, hiszen Csehország külföldi követelései még meg is haladják az ország külföldi adósságát). 


\section{5. ábra}

A fejlettség és a GDP-arányos GNI közötti kapcsolat 2015-ben

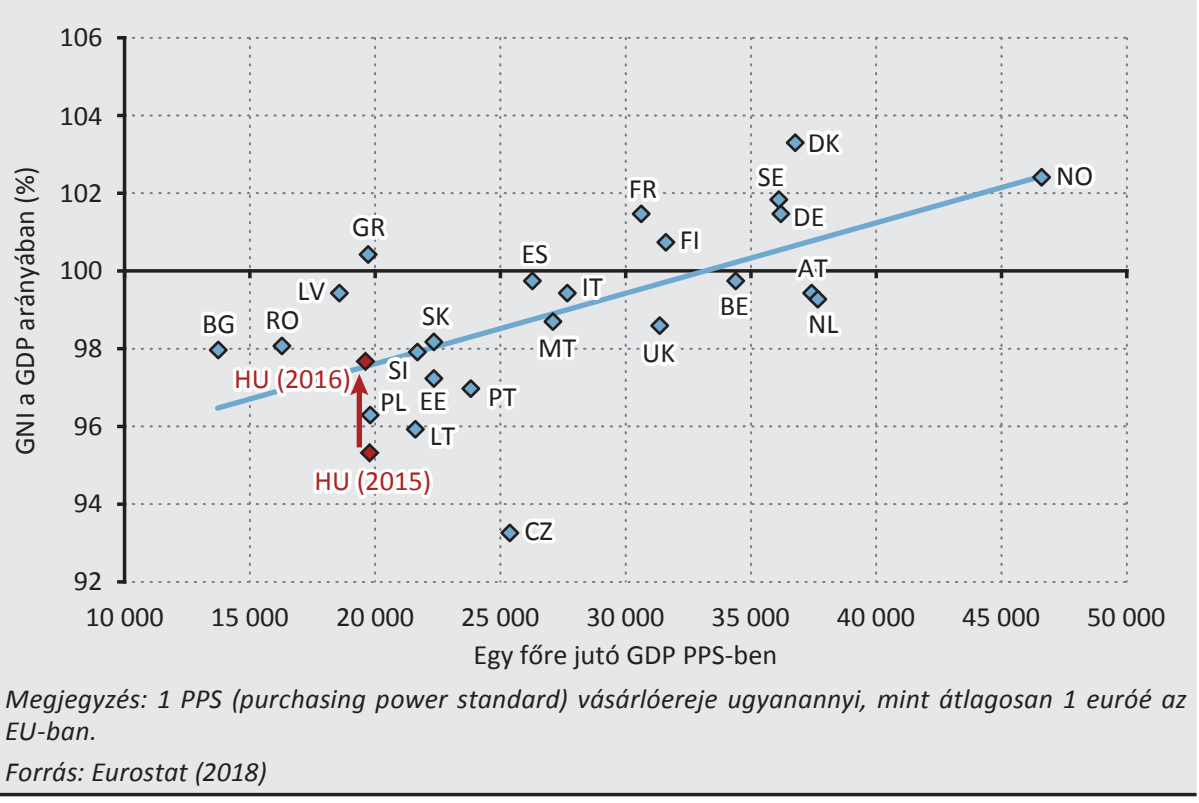

A fejlett nyugati gazdaságok nettó külföldi eszközállománya magasabb a kevésbé fejlett országokénál (16. ábra), az ehhez kapcsolódó jövedelem pedig meghatározó szerepet játszik a GNI alakulásában. A fejlettséggel párhuzamosan javuló nemzetközi befektetői pozíció több tényezőre is visszavezethető (Lane - Milesi-Ferretti 2002).

- Egyrészt a gazdasági fejlődéssel a tőke hazai határterméke egyre kisebb lesz, csökken a hazai beruházások jövedelmezősége, így a külföldre történő - magasabb jövedelmezőségú - beruházások előtérbe kerülhetnek. A magasabb jövedelmú országokban ezért a kifektetett közvetlen tőke jellemzően nagyobb, mint az adott országban befektetett FDI, az ebből származó nettó jövedelembeáramlás pedig növeli a GNI-t.

- Másrészt a háztartások jövedelmének emelkedése - a fogyasztás határhasznának csökkenése mellett - a megtakarítások emelkedéséhez vezet, amelynek egy része külföldre áramlik, tovább növelve a nettó külföldi eszközök állományát, és ezen keresztül a GNI-t.

- Emellett a fejlettebb országokban a magasabb GNI irányába hathat, hogy a külföldi forrásbevonás jellemzően FDI helyett inkább adósságtípusú forrásokból történik, az ezekre fizetett kamat pedig jellemzően kisebb, mint a befektetett tőke utáni profit. Ezzel szemben a felzárkózó országokban korlátozottabb a lehetőség az adósságból történő finanszírozásra, mivel a külföldi befektetők inkább 
a részesedés típusú befektetési formákat részesítik előnyben, amelyek a magasabb elvárt hozam mellett több irányítási és információs jogot biztosítanak (Komáromi 2008).

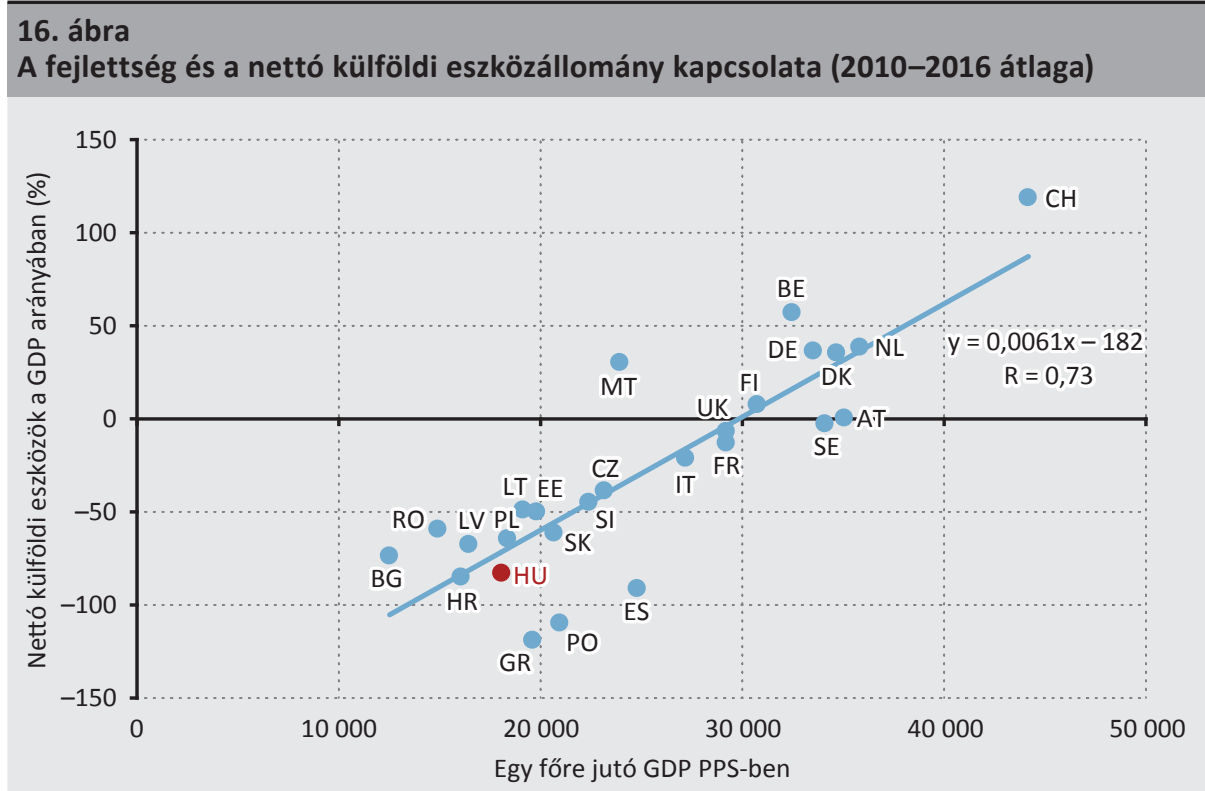

Megjegyzés: 1 PPS (purchasing power standard) vásárlóereje ugyanannyi, mint átlagosan 1 euróé az EU-ban.

Forrás: Eurostat (2018)

Magyarország magas jövedelmü országok közé történő sikeres felzárkózása hoszszabb távon a GDP-GNI rés mérséklődését eredményezheti. A hazai gazdaság fejlettségének növekedésével javulhat Magyarország nettó nemzetközi befektetési pozíciója (Koroknai 2008), ami mérsékelheti a külföldre történő nettó jövedelemkiáramlást. A magyar gazdaság versenyképességének javulása emellett támogathatja a külföldön működő magyar vállalatok jövedelmének emelkedését is, ami a magyar gazdaság belső forrásokból történő finanszírozásával együtt csökkentheti a nettó FDI-jövedelem-kiáramlást, és ezáltal a GDP-GNI rést.

\section{6. Összegzés}

Az elmúlt évtizedekben a globalizáció térnyerésével a hazai gazdaság termelése és a rezidensek jövedelme elnyíltak egymástól, így a közgazdaságtanban egyre nagyobb igény jelentkezett olyan makrogazdasági indikátorok iránt, amelyek a GDP-t kiegészítve többletinformációt adhatnak a jövedelmek egyes gazdasági szereplők közötti megoszlásáról. A bruttó nemzeti jövedelem a GDP-t korrigálja a külföldi rezidensek Magyarországról származó és a belföldi rezidensek külföldről származó 
jövedelmének egyenlegével, így a GDP-tól való eltérése megragadja a hazai gazdasági teljesítmény és a belföldi gazdasági szereplőknek jutó jövedelmek különbségét, illetve hasznos információt ad az ország felhalmozott nettó külföldi kötelezettség állományának folyó terheiről. Magyarországon a válság előtt a GDP-GNI rés régiós összevetésben magas volt, azonban a válság után fokozatosan a régiós átlag körüli szintre csökkent. A mérséklődés több tényező együttes hatásaként alakult ki: míg a részesedésekhez, közvetlentőke-befektetésekhez kapcsolódó jövedelemkiáramlások (vállalati profit) bővülése növelte, addig az alacsony hozamkörnyezet és a mérséklődő bruttó külső adósság miatt csökkenő kamatkiadások, valamint a külföldről származó bérjövedelmek dinamikus növekedése - a régió legtöbb országához hasonlóan - mérsékelték a GDP-GNI különbséget.

A GDP és GNI közötti eltérés jelentős részét a külföldi tulajdonban lévő Magyarországon múködő vállalatok jövedelme teszi ki. A GDP-GNI rést meghatározó közvetlentőke-befektetések jövedelmei főként a feldolgozóiparhoz kötődnek, és az eurozóna magországaiba, ezen belül Németországba és Hollandiába áramlanak. A GDP-GNI rés szűkülése - szektorális bontásban vizsgálva - az állam és a vállalati szektor GDP-arányos jövedelmének emelkedése mellett valósult meg, miközben a háztartásoké fokozatosan mérséklődött. Ezen folyamatok hátterében föként a bérhányad nemzetközi szinten megfigyelt csökkenése, a kamatkiadások mérséklődése, illetve az állami adóbevételek emelkedése állt.

Elöretekintve rövid távon a GDP-GNI rés várhatóan enyhén növekedik, mivel a továbbra is jelentős gazdasági növekedés, illetve a társasági adó csökkentése a külföldi tulajdonú vállalatok tôkejövedelmének emelkedéséhez vezethet. Emellett a hazai bérdinamika támogathatja a külföldön munkát vállaló magyarok visszaáramlását a magyar munkaerőpiacra, ami a külföldről származó munkavállalói jövedelmek csökkenésén keresztül önmagában a GDP-GNI rés növekedése irányába hat, ugyanakkor a magyar munkavállalók visszatelepülése hosszabb távon pozitívan hat a növekedésre. Ezzel szemben a területalapú EU-támogatások hosszabb távon is stabil nettó jövedelembeáramlást jelentenek Magyarország számára, ami mellett a csökkenő külső adóssághoz kapcsolódó kamatkiadás továbbra is a GDP-GNI rés szűkülésének irányába hat. A nemzetközi tapasztalatok tükrében a magyar gazdaság felzárkózásával párhuzamosan az eltérés hosszabb távon szúkülhet: a fejlettebb országokban ugyanis jellemzően kisebb a GDP és GNI közötti eltérés, aminek hátterében a fejlettséggel általában javuló nettó nemzetközi befektetői pozíció áll. Az eltérés hosszú távú alakulása jelentősen függ attól, hogy a magyar gazdaság nyugati országokhoz történő felzárkózása külföldi vagy belföldi forrásokból valósul meg. 


\section{Felhasznált irodalom}

AMECO (2017): AMECO database. Economic and financial affairs, European Commission. 9 November. http://ec.europa.eu/economy_finance/ameco/user/serie/SelectSerie.cfm

Balatoni András - Pitz Mónika (2012): A müködőtőke hatása a bruttó nemzeti jövedelemre Magyarországon. Közgazdasági Szemle, 59(1): 1-30.

BEA (2015): Measuring the Economy: A Primer on GDP and the National Income and Product Accounts. Bureau of Economic Analysis, U. S. Department of Commerce. Washington, DC, December. https://www.bea.gov/national/pdf/nipa_primer.pdf

Capelli, C. - Vaggi, G. (2013): A better indicator of standards of living: The Gross National Disposable Income. DEM Working Paper Series 062, University of Pavia, Department of Economics and Management.

Costanza, R. - Hart, M. - Posner, S. - Talberth J. (2009): Beyond GDP: The Need for New Measures of Progress. The Pardee Papers No. 4., Boston University, January.

Csortos Orsolya - Kóczián Balázs (2017): A külföldön élő magyarok jövedelmeinek és folyó átutalásainak elemzése. Hitelintézeti Szemle, 16(2): 5-27. http://doi.org/10.25201/ HSZ.16.2.527

Eurostat (2018): Statistics Database. http://epp.eurostat.ec.europa.eu/portal/page/portal/ statistics/search_database. Letöltés ideje: 2018. január 10.

Komáromi András (2008): A külső forrásbevonás szerkezete: Kell-e félnünk az adóssággal való finanszírozástól? MNB-Szemle, 2008(Április): 14-23.

Koroknai Péter (2008): Magyarország külföldi tartozása nemzetközi összehasonlításban. MNB-Szemle, 2008(December): 13-18.

KSH (2009): GNI Inventory 2.1. Magyar nyelvű változat. Központi Statisztikai Hivatal. https://www.ksh.hu/docs/hun/xftp/modsz/gni_inventory_ver2.1hun.pdf

KSH (2018): STADAT táblák. Központi Statisztikai Hivatal. http://www.ksh.hu/stadat. Letöltés ideje: 2018. január 10.

Lane, P.R. - Milesi-Ferretti, G.M. (2002): Long-Term Capital Movements, NBER Chapters. In: NBER Macroeconomics Annual 2001, Volume 16, pages 73-136 National Bureau of Economic Research, Inc. https://doi.org/10.1086/654435

Lucas, R. (1990): Why doesn't Capital Flow from Rich to Poor Countries? American Economic Review, 80(2): 92-96. 
MNB (2014): Fizetési mérleg jelentés. Magyar Nemzeti Bank, szeptember.

MNB (2016a): A külföldiek magyarországi közvetlentőke-befektetés állományának végső befektetők szerinti bontása. Magyar Nemzeti Bank. http://www.mnb.hu/letoltes/akozvetlentoke-befektetes-allomany-vegso-befektetore-allokallasa-honlapra.pdf.Letöltés ideje: 2018. január 10.

MNB (2016b): Fizetési mérleg jelentés. Magyar Nemzeti Bank, október.

MNB (2017a): Inflációs jelentés. Magyar Nemzeti Bank, december.

MNB (2017b): Növekedési jelentés. Magyar Nemzeti Bank, december.

MNB (2017c): Fizetési mérleg jelentés. Magyar Nemzeti Bank, október.

MNB (2018): Magyar Nemzeti Bank: Fizetési mérleg, közvetlen tökebefektetések, külfölddel szembeni állományok. Magyar Nemzeti Bank. https://www.mnb.hu/statisztika/statisztikaiadatok-informaciok/adatok-idosorok/viii-fizetesi-merleg-kozvetlen-tokebefektetesekkulfolddel-szembeni-allomanyok/fizetesi-merleg-kulfolddel-szembeni-allomanyok/bpm6modszertan-szerinti-adatok. Letöltés ideje: 2018. január 10.

Oblath Gábor (2011): Makrostatisztika. ELTE TáTK Közgazdaságtudományi Tanszék.

Stapel-Weber, S. - Verrinder, J. (2016): Globalisation at work in statistics - Questions arising from the 'Irish case'. Eurona, 2: 29-44. https://ec.europa.eu/eurostat/cros/system/files/ euronaissue2-2016-art2.pdf. Letöltés ideje: 2018. január 10.

Stiglitz, J.E. - Sen, A. - Fitoussi, J-P. (2008): Report by the Commission on the Measurement of Economic Performance and Social Progress. ECB. http://ec.europa.eu/eurostat/ documents/118025/118123/Fitoussi+Commission+report. Letöltés ideje: 2018. január 10.

World Bank (2017): Why use GNI per capita to classify economies into income groupings? World Bank. https://datahelpdesk.worldbank.org/knowledgebase/articles/378831-whyuse-gni-per-capita-to-classify-economies-into. Letöltés ideje: 2018. február 28. 


\section{Függelék: A sikeresen felzárkózó országok GDP-GNI eltérésének alakulása}

A sikeres felzárkózási periódus végén jellemzően zárult a GDP-GNI rés (17. ábra). A korábban sikeres felzárkózást mutató országok tapasztalatai alapján a felzárkózás időszakában fokozatosan csökkent a GDP-GNI közötti különbség:

- Szingapúrban az FDI-beáramlás a felzárkózás során végig fontos finanszírozási tétel volt, a beruházások jelentős hányada valósult meg közvetlentőke-befektetésekből. Ennek megfelelően a felzárkózás kezdeti időszakában a GDP és GNI közti különbség számottevő mértékben tágult. A nyolcvanas évek közepétől jellemző - elsősorban adósság típusú - kifektetéseknek köszönhetően azonban a rés záródásnak indult.

- Finnországban a kezdetben érdemi forrásbeáramlás a felzárkózás során lelassult, ami a GDP-GNI rés záródásához vezetett.

- Dél-Koreában és Ausztriában a GNI és a GDP alig vált el egymástól, ami azzal állhatott összefüggésben, hogy a nettó külső forrásbevonás sem volt számottevő.

- Írország kivételnek számít abból a szempontból, hogy a kedvező adórendszernek köszönhető FDI-beáramlás a GDP megugrását okozta, emellett azonban az adósság típusú tartozásállomány is érdemben emelkedett. Ezek összességében a GDP és a GNI közötti különbség számottevő eltéréséhez vezettek, aminek lassulása csak a nyolcvanas évek végén meginduló adósság típusú forrásokat érintő alkalmazkodás után következett be.

Összességében elmondható, hogy a sikeresen felzárkózó országokban a GDP-GNI rés általában nulla közelébe csökkent a felzárkózási periódus végére.

17. ábra

A GDP-GNI rés a sikeresen felzárkózó államokban

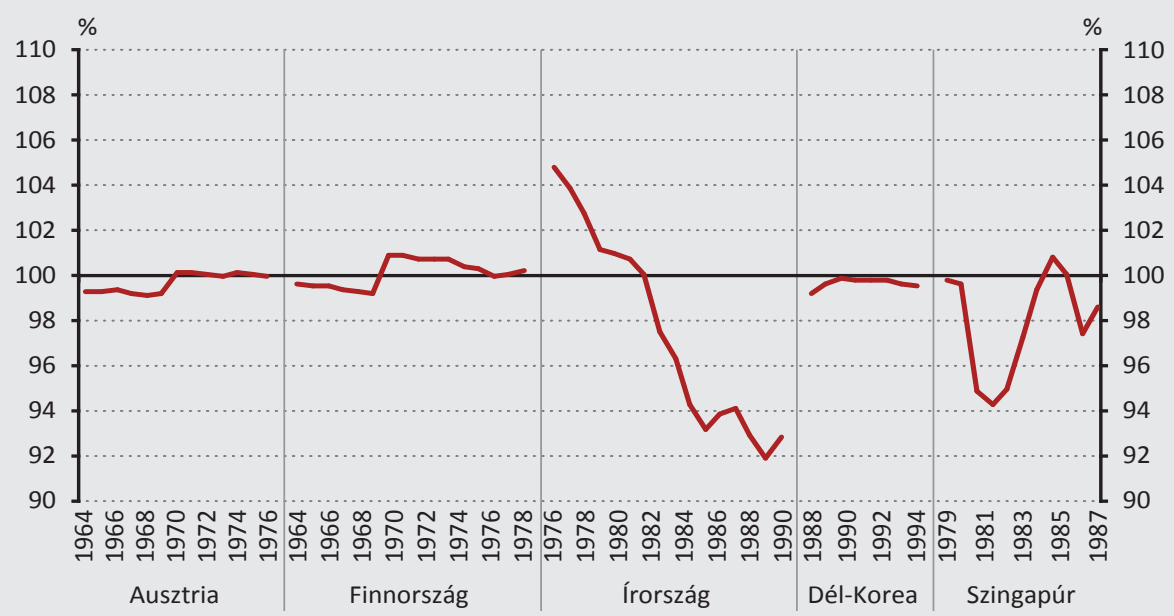

Forrás: World Bank 


\section{Függelék: Mit mutat a GNI-ban megjelenő FDI-jövedelem?}

A vállalati szektorban kimutatott jövedelem a - statisztikai módszertannak megfelelöen - a vállalatok normál müködési tételeinek eredménye, ami jellemzően magasabb, mint a vállalatok adózott eredménye (18. ábra). A válságot követő években a vállalati szektor adózott eredménye jelentősen visszaesett, amit egyszeri tételek (pl. a bankoknál a devizahitelek kedvezményes árfolyamon történő átváltása, hitelezési veszteségre történő elhatárolások) is befolyásoltak. Ezzel szemben a fizetési mérlegben és így a GDP-GNI közötti különbségben a külföldi vállalatok jövedelme csak kisebb mértékben esett vissza, és minden évben pozitív maradt. Az eltérést az magyarázza, hogy a GNI-GDP résben a fizetési mérleghez hasonlóan nem a vállalatok (és így a bankok) adózott eredménye jelenik meg, hanem az úgynevezett normál üzletmenet szerinti eredményük (a megközelítés angol neve COPC - Current Operating Performance Concept). Ez a korrigált eredménytétel a vállalatok normál üzletmenet szerinti eredményét tartalmazza, és kiszűri az egyszeri, nem tartósnak tekinthető, általában az árfolyamok elmozdulásából származó eredménytételek hatását (MNB 2014). 2008 és 2014 között a pénzügyi és nem pénzügyi vállalati szektorban ennek a korrekciónak a mértéke évente átlagosan a GDP 2,4 százalékát tette ki, míg 2015-ben egy multinacionális vállalatcsoport nemzetközi átszervezéséhez kapcsolódó jelentős egyszeri nyereség, majd 2016-ban egy ehhez hasonló mértékű veszteség befolyásolta jelentősen a vállalatok adózott eredményét. Mivel azonban ezek a tételek nem tekinthetők tartósnak, ezért nem tükröződnek a fizetési mérleg jövedelmei, és így a GDP-GNI közötti különbségben sem.

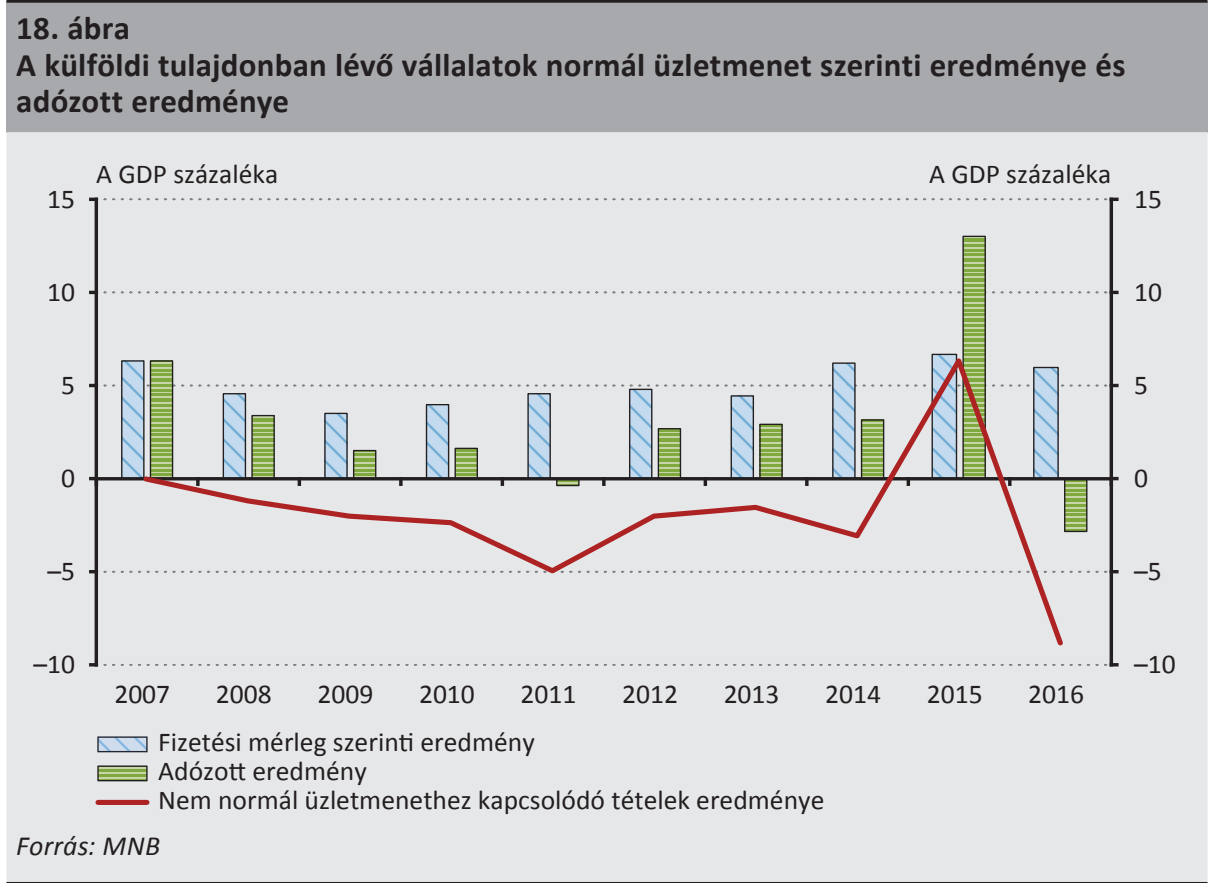


A GNI-ban megjelenö FDI-jövedelmeket a statisztikai elszámolás mellett a vállalatok egyedi adóoptimalizációs döntései is befolyásolják. Amennyiben a vállalatok jövedelme az egyes országok között még az adózás előtt átcsoportosításra kerül (például egy vállalat licenchasználati díjat fizet az anyacégnek), az a fizetési mérleg más tételeinek (jellemzően import) növekedése mellett a profitjövedelem csökkenését eredményezi. A jogszabályok alapján a kapcsolt vállalkozások közötti kereskedés elszámolásakor piaci árakat kell használni, ami elméletileg biztosítja, hogy ne legyen lehetőség visszaélésekre, ugyanakkor a multinacionális cégeknél e piaci ár melletti értékesítés is jelentős jövedelemátcsoportosítást jelenthet. Aggregált adatok hiányában nem lehet számszerúsíteni, hogy ezen stratégiák milyen nagyságrendben és irányban befolyásolják a hazai nettó FDI-jövedelem-kiáramlást, azonban érdemes felhívni a figyelmet ennek szerepére a GDP-GNI közötti eltérés alakulásában.

Bár a teljes vállalati jövedelem csökkenti a GNI értékét, ez nem jelenti azt, hogy ezt a jövedelmet tulajdonosok számára kiutalták a vállalatok, mivel ennek jelentős részét újra befektették a gazdaságban - ez ugyanakkor külső forrásként jelenik meg a vállalatoknál. Bár a GDP-GNI közötti különbségben a teljes vállalati jövedelem megjelenik, ez nem jelenti ezen jövedelmek hazautalását. A GDP-GNI közötti különbség csak a jövedelemtulajdonosok közötti eltérést mutatja be. A megtermelt jövedelmet a vállalatoknál tovább bonthatjuk aszerint, hogy azt a tulajdonosa osztalékként kifizette (praktikusan hazautalta) vagy pedig az adott gazdaságban újra befektette. Vagyis a GDP-GNI közötti különbségben megjelenő vállalati jövedelem egy része ténylegesen nem hagyja el a gazdaságot, hanem a tulajdonosok „visszaforgatják", és a vállalat további múködését, beruházásait finanszírozza. 